\title{
Fiscal-Monetary-Financial Stability Interactions in a Data-Rich Environment
}

\author{
Martin Hodula, ${ }^{1}$ Lukáš Pfeifer ${ }^{2}$
}

\begin{abstract}
In this paper, we shed some light on the mutual interplay of economic policy and the financial stability objective. We contribute to the intense discussion regarding the influence of fiscal and monetary policy measures on the real economy and the financial sector. We apply a factor-augmented vector autoregression model to Czech macroeconomic data and model the policy interactions in a data-rich environment. Our findings can be summarized in three main points: First, loose economic policies (especially monetary policy) may translate into a more stable financial sector, albeit only in the short term. In the medium term, an expansion-focused mix of monetary and fiscal policy may contribute to systemic risk accumulation, by substantially increasing credit dynamics and house prices. Second, we find that fiscal and monetary policy impact the financial sector in differential magnitudes and time horizons. And third, we confirm that systemic risk materialization might cause significant output losses and deterioration of public finances, trigger deflationary pressures, and increase the debt service ratio. Overall, our findings provide some empirical support for countercyclical fiscal and monetary policies.
\end{abstract}

Key words: financial stability, fiscal policy, macroprudential policy, monetary policy, interactions, policy mix

JEL Classification: E44, E61, G28

Received: 20 March 2018/Accepted: 24 May 2018 / Sent for Publication: 3 September 2018

\section{Introduction}

Successful implementation of macroprudential policies requires, among other things, a good understanding of the interplay between economic policies, their respective targets, and financial sector development. In this context, there is an intense policy debate focused on determining the extent to which fiscal and monetary policy measures may influence the functioning of the financial sector (i.e. the financial cycle). This debate has generated interest in analysing the quantitative importance of policy transmission channels to the financial sector, their mutual coordination, and the implementation of macroprudential policy tools in smoothing the financial cycle.

\footnotetext{
${ }^{1}$ VŠB-Technical University of Ostrava, Economic Faculty, Department of Economics, 15/2172 17. Listopadu St., 70833 Ostrava, Czech Republic, e-mail: martin.hodula@ vsb.cz

${ }^{2}$ University of Economics in Prague, Department of Monetary Theory and Policy, 1938/4 W. Churchill Sq., 13067 Prague 3, Czech Republic, e-mail: 1.pfeifer@ seznam.cz 
In this paper, we contribute to that debate by presenting comprehensive time-series evidence on the fiscal-monetary-macroprudential policy interactions in a data-rich environment. We differ from the rapidly expanding body of literature on monetary/fiscal policy and macroprudential policy interactions mainly in that we consider both policy shocks simultaneously and identify a specific policy mix that might increase systemic risk in the financial sector. Further, we also consider the kick-back effect of financial instability and analyze its propagation in the real economy. In the process, we aim to answer the following questions: First, does loose economic policy benefit financial stability? Second, do fiscal and monetary policy shocks impact the financial sector differently? And third, how do financial imbalances influence real economic activity? The analysis is conducted for the Czech Republic, a small open economy that went through a transformation process from a centrally-planned to a market-based economy in the 1990s. The selection of the country is purely pragmatic; the Czech Republic has a bankbased financial sector dominated by foreign capital and ranks among the most open economies in Europe.

After the Lehman crash, many of the pre-crisis claims, such as monetary policy's 'benign neglect' approach to asset price development or a strict division of labour between different policy levers, began to be questioned. Even the New Keynesian models, which implied that ceteris paribus price stability would be a sufficient condition for output to remain close to its natural level, were subject to criticism. Studies generally conclude (regarding the pre-crisis development) that the low-interest-rate environment in the precrisis period led to the formation of financial imbalances while associated fiscal stimuli during credit booms only deepened systemic risk (see Taylor, 2009; Obstfeld and Rogoff, 2009, for policy discussion, or Adrian and Liang, 2016, for empirical analysis). The subsequent financial crisis then led to deflationary pressures and an unprecedented (apart from wartime) increase in public debt levels in developed countries. ${ }^{3}$ The increase in sovereign default risk further lowered trust in deposit insurance systems and, in general, reduced the ability of fiscal policy to support economic growth. Therefore, it is only logical to question the role of economic policy in determining economic growth and maintaining financial stability.

After the crisis, a new set of tools was introduced to reduce the procyclical character of economic policy. Its mandate is to prevent the accumulation of systemic risk and the formation of financial crises using prudentially-tuned measures of macroprudential policy. In the present day, it is becoming obvious that fiscal, monetary, and macroprudential policy affect each other and a strategic conflict may arise in certain situations. Therefore, Borio (2017) claims that counter-cyclical economic policy settings are now crucial, as global debt levels are at a historical high point and room for policy manoeuvring is remarkably narrow. In this context, achieving some form of coordination between economic policy and financial stability objectives seems to be a fundamental task. In fact, keeping the financial sector stable should be in the best interests of both monetary and fiscal policy, given the excessive costs of financial instability.

The remainder of the paper is organized as follows: Section 2 serves as a review of the literature published on the topic so far. Section 3 outlines the theoretical underpinnings

\footnotetext{
${ }^{3}$ Bank for International Settlements (2016) states that the public debt-to-GDP ratio increased in developed economies by more than 50 percent.
} 
of the empirical framework applied and describes the data employed. Section 4 discusses empirical results, and Section 5 concludes and describes some of the outstanding challenges.

\section{Literature review}

\section{Monetary policy and financial stability}

A fierce debate on the interaction between economic policy and financial stability erupted after the most recent financial and economic crisis in 2007-2008 and to this point, a number of both theoretical and empirical studies were published. Attention was primarily given to the interplay of monetary policy and asset prices - a relationship that turned out to be crucial prior to the crisis. Kuttner (2013) provides an overview of the empirical findings both prior to and after the crisis. Current generally-accepted theory holds that one may expect asset prices to decrease following a contractionary monetary policy shock through the functioning of an asset-price channel. However, Galí and Gambetti (2015), using a time-varying framework, find protracted periods during which stock prices increase after a monetary tightening. On the other hand, Paul (2018) finds that stock prices always decrease following contractionary monetary policy shocks, while Aastveit et al. (2017) find that Fed episodically took real stock price growth into account. Still, stock price developments do not have a significant impact on monetary policy decision-making due to their higher volatility. In this area, housing prices are frequently discussed, as they are considered an early-warning indicator (Gramlich et al., 2010, Babecky et al., 2013; Laina et al., 2015), and tended to increase sharply before the crisis. Therefore, many authors have argued for the inclusion of residential real estate prices in the consumer price index and the monetary policy decision-making process (e.g Goodhart 2001; Aydin and Volkan, 2011; Hampl and Havranek, 2017). They argue that this could lead to smoother business cycle fluctuations compared to conventional inflation targeting.

In this context, there has been a renewed "lean or clean" debate aimed at verifying whether the central bank should incorporate asset price development into its decisionmaking process, even when the current inflationary target is not at risk. Up until the crisis, monetary policy practitioners only responded to asset prices if and when associated risks actually materialized and were transmitted into the real economy ("clean up afterwards" strategy). Even today, this approach has its advocates. Svensson (2016) provides a comprehensive discussion and review of existing empirical studies and concludes that "leaning against the wind" is still not fully justified. However, in light of recent empirical evidence showing that loose monetary policy influences asset prices, risk appetite, and financial stability in general, a growing number of studies favour the leaning against the wind strategy (see Smets, 2014, for a review). Those studies claim that monetary policy should respond to financial risk accumulation to forestall these risks' materialization and the associated negative impact on the real economy (Filardo and Rungcharoenkitkul, 2016).

Following this intense discussion, a consensus of sorts emerged in the form of a macroprudential policy toolset to complement existing capital and liquidity regulations. In many countries, macroprudential policy represents an autonomous branch of economic policy with its own objectives (financial stability) and tools. This new paradigm has 
given rise to a new set of questions regarding the extent to which monetary policy is able to influence financial sector development, as well as the relative positions of monetary and macroprudential policy, and their respective targets.

In theory, the impact of monetary policy on financial stability is related to monetary policy transmission channels: the asset-price channel, the bank-lending channel, and the balance-sheet channel. Theory suggests that lower interest rates should strengthen financial stability. Loose monetary policy is, under general circumstances, transmitted to lower lending rates (the bank-lending channel). Thus, loans become cheaper and more attractive, which then increases the volume of assets, the share of loans on total assets, and banks' profitability. This also improves the balance sheets of economic subjects (the balance-sheet channel). Hoffman and Peersman (2017) also speak of a new channel of monetary policy that works through the debt service ratio, defined as total debt payments to the income of the private non-financial sector. Hoffman and Peersman (2017) and Juselius et al. (2017) argue that monetary expansion leads to a decrease in the debt service ratio, with lower interest rates on the stock of debt outweighing a rise in the debt-to-income ratio. Drehmann and Juselius (2012) and Lombardi et al (2017) further state that changes in the debt service ratio can have aggregate macroeconomic effects and significantly influence financial stability.

Also, one must not forget that keeping interest rates low in the long term may induce households and firms to gradually increase leverage through the conventional intertemporal substitution effect (for more detailed discussion see ESRB, 2016, and IMF, 2015). Even commercial banks are influenced by the low interest rate environment, as to maintain their profitability, they need to change their portfolio structure in favour of riskier assets. Borio and Zhu (2012) describe this as the risk-taking channel of monetary policy. Recent empirical studies have already shed some light on its functioning (Angeloni et al., 2014; Abbate and Thaler, 2015; Gilbert et al., 2018, to name a few). Borio (2014a) claims that accumulation of financial disequilibrium occurs most often during positive supply shocks, which push down prices while enhancing optimistic expectations and investment into riskier assets.

Several studies stress the need for some form of policy coordination between monetary and macroprudential policy. The need for such coordination stems from the observation that monetary and macroprudential policy tools are not independent, as they affect both the monetary and credit conditions via their effect on credit growth (Malovana and Frait, 2017). At the same time, the best economic outcomes can be expected if both policies are used in a complementary manner and are executed by a single institution (Libich, 2017). Galati and Moessner (2013) provide an overview of research on monetarymacroprudential policy interactions.

\section{Fiscal policy and financial stability}

During the recent financial crisis, extraordinary measures were taken, not only by central banks but by governments as well, to prevent a collapse of the financial sector. Support packages from governments reached unprecedented levels and, despite the fact they might endanger fiscal deficits (Agnello and Sousa, 2009) and long-term debt sustainability (Hallet and Lewis, 2008; Schuknecht et al., 2009), they are being justified by the idea that fiscal policy might be used to help economic recovery and, if executed properly, to foster financial stability. In this spirit, BIS (2016) claims that fiscal policy 
should be, compared to the current state of affairs, much more countercyclical. Fiscal policy should therefore in times of financial boom generate a budgetary surplus and create sufficient fiscal space for subsequent financial cycle contraction. ${ }^{4}$ Governments however often use economic growth to increase mandatory expenditures or government investments, which, despite overall positive economic development, lead to a negative primary balance. Therefore, fiscal policy's manoeuvring space may be substantially limited, especially due to ill-considered fiscal policy strategies during an economic boom. Still, to this day there is no unified view on the linkages between fiscal policy and asset prices. This is due to the fact that not all asset prices react alike to fiscal policy shocks (Agnello and Sousa, 2013), and that the fiscal and financial sector are inherently interlinked, making it hard to identify specific effects and their direction.

To explain the interlinking in a more rigorous manner, let us consider the channels through which changes in sovereign risk may affect banks. One such channel works through the banks' direct holding of sovereign debt (the asset holding channel). In general, a financial boom often supports sovereign credit, which lowers the risk of sovereign default and improves banks' portfolios. Also, banks often use sovereign securities as collateral to secure wholesale funding from central banks, private repo markets, and issuance of covered bonds, and to back OTC derivative positions. So, when the price of sovereign bonds increases, the value of the collateral automatically increases as well (the collateral channel). Ari (2016) shows that during a crisis, banks become heavily exposed to domestic sovereign bonds, which may lead to a rise in bank funding costs and the crowding out of bank lending to the private sector. Deev and Hodula (2016) add that in cases where government-owned banks directly participate in large governmental projects, banking fragility may result in the deterioration of state funds while also raising the risk of sovereign default. Also, one must not forget that sovereign ratings often represent a ceiling for the rating of domestic financial institutions, and thus any upgrade in a country's rating also affects local banks (the ratings channel). These channels, when working in the positive direction during a financial boom, may greatly improve banks' balance sheets and the availability of additional capital funding.

During a financial cycle contraction, however, government debt usually grows because of a decrease in economic activity and asset prices. According to Borio et al. (2015), economic output is negatively influenced for many years after a crisis. ${ }^{5}$ During a financial crisis, asset prices significantly decrease and affect consumption and thereby indirect taxes via wealth effects. The growth of non-performing loans and decline in asset prices can also undermine the health of private financial institutions. In such cases, the government may be forced to recapitalize such institutions from public funds (bail-out costs). ${ }^{6}$ There are also likely to be second-round effects on fiscal variables, particularly

\footnotetext{
${ }^{4}$ See e.g. BIS papers: Borio and Lowe (2002), Drehmann et al. (2012), Borio (2014b).

${ }^{5}$ They state that during boom periods, factors of production are being moved to less productive and more procyclical sectors (e.g. construction). This inevitably deepens and prolongs the economic slowdown during financial stress and also weakens the sustainability of public debt.

${ }^{6}$ For the rare occasions when problems in the financial sector reach this scope, a financial crisis resolution mechanism was formed (according to the Bank Recovery and Resolution Directive BRRD). Their aim is to prevent the need for bank recapitalization from public funds and therefore to prevent a financial crisis having a one-time negative impact on fiscal sustainability.
} 
when significant financial instability feeds back into the economy (for a more detailed description of transmission channels, see Eschenbach and Schuknecht, 2004).

\section{Fiscal-monetary-financial stability interactions}

Overall, the existing research on fiscal- and monetary-financial stability interactions may be grouped into two strands. One strand analyzes the effects of monetary and fiscal policies on the real economy and the financial sector separately, and abstracts from the interlinkages between individual economic policy measures. A review of such studies, although by no means exhaustive, was presented in the previous sub-sections. The second, ever-expanding strand of literature analyzes the behaviour of economic agents in terms of interaction and exchange of information. Over time, it became crucial to account for the fact that both monetary and fiscal policy influence one another and interact with their broad set of instruments. This interaction and the (in)compatibility of their measures give rise to various impacts on the real economy and financial sector. It is reasonable to expect that none of the institutions involved will completely ignore the behaviour of other economic policy agents. The theoretical foundations of fiscal and monetary policy interactions are well established in the literature (Sargent and Wallance, 1981; Leeper, 1991; Woodford, 1996, among others). Empirical attempts to analyze policy interactions may be found e.g. in Muscatelli et al.(2004), Mountford and Uhlig (2009), Rossi and Zubairy (2011) and recently in Bianchi and Ilut (2017) and Orphanides (2017). These studies adopt different approaches to the analysis, but the authors generally agree that monetary and fiscal policies do not contradict themselves in the event of shocks to output (supply or demand shocks) and can act as substitutes in the case of inflation shocks or shocks affecting individual economic policy instruments. We contribute to this literature by providing comprehensive time series evidence on fiscalmonetary-financial stability interactions. We do so in a flexible framework using information from hundreds of macroeconomic time series, which significantly lowers the information bias. We rely mainly on Czech macroeconomic data, but our modelling framework can be extended to other economies.

The theoretical foundations of policy and financial stability interactions can be found in Woodford (2011) and Carlstrom et al. (2010). Ueda and Valencia (2014) build a model based on a loss function with three elements: variations of output, inflation, and private sector leverage. They derive the following, rather intuitive equation:

$$
\ln (\Phi)=\varphi: \varphi_{t-1}-\left(\pi_{t}-\pi^{e}\right)-\left(y_{t}-y^{e}\right)+\delta_{t},
$$

which shows that ex-post leverage in the economy is given by surprises in inflation $\left(\pi_{t}-\pi^{e}\right)$, output $\left(y_{t}-y^{e}\right)$, and credit growth $\delta_{t}$. Credit growth is in turn determined by regulatory measures and credit shocks. The relationship described in (1) suggests that the increase of deviation from equilibrium of inflation $\left(\pi_{t}-\pi^{e}\right)$ and output $\left(y_{t}-y^{e}\right)$ lowers private sector leverage $\Phi$. Assuming that the financial risk is positively correlated with the level of leverage, eq. (1) suggests that loose economic policies lower financial risks in the economy and therefore the risk of financial instability in the future. In this paper, we argue that the functioning of the economy might not be as straightforward as the theoretical models suggest, as the effect could go either way, i.e., may be positive or negative, and is significantly time-dependent. 


\section{Empirical methodology}

To study the fiscal-monetary-financial stability interactions, we use the factoraugmented vector autoregression model (FAVAR) introduced in Bernanke et al. (2005). Our primary motivation for choosing the FAVAR model is to avoid the information bias when identifying the set of economic policy innovations. ${ }^{7}$ Also, we want to use the advantageous logic of VAR models, which are a theory-free way to "let the data speak" about causality questions. Last, one can find many types of autoregressive patterns in macroeconomic and financial time series, implying that the real economy does not constitute a random entity. A VAR model accounts for these patterns and, for each variable entering the model, computes an equation explaining the variable's evolution based on its own and other variables' lagged values.

In contrast to a simple VAR model, the FAVAR model includes unobserved lowdimensional factors in the autoregression, reducing the information bias. The FAVAR model thus utilizes the advantages of a data rich environment, while remaining tractable in terms of the number of parameters to be estimated. We specify an $M \times 1$ vector of macroeconomic time series $Y_{t}$ and a $K \times 1$ vector of unobserved factors $F_{t}$. We assume that the joint dynamics of $F_{t}^{\prime}, Y_{t}^{\prime}$ is given by the following equation:

$$
\left[\begin{array}{l}
F_{t} \\
Y_{t}
\end{array}\right]=\Phi(L) \cdot\left[\begin{array}{l}
F_{t-1} \\
Y_{t-1}
\end{array}\right]+\varepsilon_{t},
$$

where $\Phi(L)$ is a lag polynomial and $\varepsilon_{t}$ is an error term with zero mean and covariance matrix Q. Equation (2) is a standard VAR model that can be interpreted as a reduced form of a linear rational-expectations model with both observed and unobserved variables. The unobserved variables make the model impossible to estimate; therefore, we assume that the additional informational time series $X_{t}$ are linked to the unobservable factors $F_{t}$ and the observable factors $Y_{t}$ by:

$$
X_{t}^{\prime}=\Lambda^{f} F_{t}^{\prime}+\Lambda^{y} Y_{t}^{\prime}+e_{t}^{\prime},
$$

where $\Lambda^{f}$ and $\Lambda^{y}$ are matrices of factor loadings and $e_{t}^{\prime}$ is a serially uncorrelated error term with a zero mean (innovation shock). Equation (3) captures the idea that both vectors $Y_{t}^{\prime}$ and $F_{t}^{\prime}$ are pervasive forces that might drive the common dynamics of $X_{t}$. This static representation of the dynamic factor model enables us to estimate the factors by principal components. As the static factors incorporate information from a large number of economic variables, the information set of the structural factor model is far greater than that of a standard VAR. Thus, it becomes unlikely that the information set

\footnotetext{
7 A situation in which the econometrician's information set is smaller than that of the economic agents. If this is the case, the relatively small number of variables in a small model may not be sufficient to properly identify shocks, which increases the risk of a biased estimate. For example, when trying to identify a monetary policy shock in a VAR model, the shock may actually not be truly exogenous, as it may also capture instances when the central bank endogenously reacts to changing inflation expectations. Forni and Gambetti (2010) demonstrate that non-fundamentals can account for the well-known VAR price puzzle and the delayed overshooting puzzle. Similarly, Iwata (2013) discusses two fiscal policy puzzles and their possible explanations.
} 
of economic agents will be superior to the information set employed by us. In our application, the we assume that the vector of observable variables $Y_{t}$ holds only our specified innovations, which are then assumed to have pervasive effect on the entire economy. Note that any remaining time series from our vast dataset may be linked to the factors outside of the VAR model via factor loadings identified by the principal component analysis. For details on the estimation procedure, please consult the Appendix $\mathrm{C}^{8}{ }^{8}$

\section{Data and identification scheme}

Our vector $X_{t}$ for factor extraction consists of a balanced panel of 140 quarterly time series representing the Czech economy and the rest of the world. They are drawn mainly from the Czech National Bank, Czech Statistical Office, and ECB databases. The data spans the period 2001:Q1 - 2016:Q1. Generally, it is not required to perform any ex ante categorization of data, but we can benefit from stacking data into sub-groups in accordance with the different classes of economic variables for the sake of the clarity of our computational process. The data sub-groups and corresponding variable counts are presented in Table 1 below. Note that prior to estimation, the data was transformed to assure stationarity of the time series using natural logarithms and first differences. By modelling the fiscal-monetary-financial stability interactions in a data rich environment, we control for real economy development, changes in fiscal and monetary policy, financial sector development, and external influences.

We identify policy innovations using recursive ordering, placing unobserved factors before observed factors. The principal assumption is that unobserved factors do not respond to policy innovations within the first quarter. In order to identify policy innovations, we divide our panel of variables into two groups: slow- and fast-moving variables. Blocks describing the external environment, real economy, fiscal variables, and prices are classed as slow-moving (in the order given in Table 1). A slow-moving variable is one that is largely predetermined in the current period and is assumed not to respond instantaneously to the specified shocks. The rest of the blocks are classed as fastmoving variables, which are assumed to be highly sensitive to contemporaneous economic news or shocks. In case of a fiscal shock, all fiscal variables are classed as fastmoving as in Lagana and Sgro (2011). Note that the variables from which we extract the innovations are always ordered last in the covariance matrix (and treated as a factor on their own). This means that we assume each of the given innovations to affect our latent factors with a lag of one quarter. Since we want to avoid a shortage of degrees of freedom, we prefer to use a smaller model with lower number of lags. The standard information criteria tests suggest three lags, but using more sensitive exclusion-based General-to-Specific approach, we find that two lags are sufficient. Therefore, our baseline FAVAR model contains two lags. Nevertheless, we check for the robustness of our results later.

\footnotetext{
${ }^{8}$ The FAVAR modelling framework is used in many economic applications, see for instance Forni and Gambetti (2010), Eickmeier and Hofmann (2013), Aastveit (2013) or Hodula and Pfeifer (2018).
} 
Table 1 Sub-groups in the dataset

\begin{tabular}{lcc}
\hline \hline Data Sub-Groups & Slow/Fast Moving & Number of Variables \\
\hline External environment & $(\mathrm{S})$ & 12 \\
Real economy & $(\mathrm{S})$ & 32 \\
Labour market & $(\mathrm{S})$ & 17 \\
Government & $(\mathrm{S})$ & 12 \\
Prices and price expectations & $(\mathrm{S})$ & 20 \\
Interest rates and credit & $(\mathrm{F})$ & 29 \\
Financial sector & $(\mathrm{F})$ & 12 \\
Exchange rates & $(\mathrm{F})$ & 6 \\
\hline \hline
\end{tabular}

Note: The Appendix lists the time series included in these sub-groups. Sub-groups highlighted in bold contain variables used as the source of an identified shock. Such variables are never included in the dataset from which we extract the factors.

We consider three types of economic policy shocks: monetary and fiscal policy expansion and systemic risk materialization. The main policy tool of the CNB is a two-week repo rate. However, because the repo rate does not change continuously but only as an outcome of CNB Board of Governors meetings, we use the inter-bank rate to proxy for the CNB's key monetary policy rate; similar to how it is done in the CNB's own forecasting system. Hence, we identify an expansionary monetary policy shock as a decrease in PRIBOR 3M. From the financial stability standpoint, an interest rate drop increases the economy's leverage and boosts the risk appetite of economic subjects, and therefore may threaten financial stability. The main fiscal policy variables are government revenue from taxes and total government expenditure, either of which may be used as a source of the innovations. However, using government revenue from taxes as a source variable increases the risk of endogeneity, since government revenue growth is associated with business cycle expansion. On the basis of these shortcomings, we identify an expansionary fiscal policy shock as an increase in total government expenditure. ${ }^{9}$ Last but not least, we consider the impact of systemic risk materialization as part of financial cycle development. We draw this information from the non-performing loans (NPL) ratio time series. During financial stress, the NPL ratio grows because of an increase in the absolute level of non-performing loans and a decrease in newly-granted loans. Hence, the systemic risk materialization shock is identified as an increase in the NPL ratio.

We conduct a number of checks to verify the robustness of our results. First, we use alternative variables and time frames during the identification of shocks. In case of monetary policy expansion, we check the robustness of results with respect to the CNB's exchange rate commitment, which started in November 2013, and the model with data ending in 2012Q1. ${ }^{10}$ By cutting the sample, we also address the fact that the

\footnotetext{
${ }^{9}$ Additionally, while changes in asset prices may influence government revenues, they are much less likely to affect government spending.

${ }^{10}$ For more details on the exchange rate commitment (and recent exit) please consult the CNB website at https://www.cnb.cz/en/monetary_policy/exit_exchange_rate_commit/index.html
} 
CNB hit the zero lower bound in 2013Q1 when it decreased its main two-week repo rate to $0.05 \%$. For fiscal policy expansion, we attempt to simulate a decrease in government revenues from taxes as an alternative measure. In addition, we also consider a different setting for the systemic risk materialization shock and use information from housing price development as a source of the shock. None of the above-mentioned changes had significant impact on the sign of estimated parameters, and therefore we claim the results to be robust in this manner. The results of these exercises are available upon request. Second, we test whether our results are affected by changing the number of factors that enter the FAVAR model. In particular, we try estimating the model with 5 and 7 factors. Most of the estimated median IRFs from the models with 5 and 7 factors lie inside the $90 \%$ confidence interval of the FAVAR model with 3 factors. The only difference is a slightly slower reaction of the variables to the monetary policy shock in the case of models with larger number of factors. Third, we use an alternative identification strategy for fiscal and monetary policy shocks. Results are robust to the use of other plausible orderings of the variables in the FAVARs: We tried ordering the external environment group of variables last, and we also changed the source of the innovation from PRIBOR $3 \mathrm{M}$ to the average lending rate to check if the results are dependent on the maturity of loans. Further robustness checks include an increased number of lags in the FAVAR model (up to 4 lags); they provide results that are both qualitatively and quantitatively similar.

\section{Empirical results}

The effects of the specified innovations are presented in Figures 1-4 using impulse response functions (IRFs) over a time window of four years (16 quarters). The IRFs show the responses of the selected variables to an identified shock and the shock's propagation over time. We plot the median responses to show the central tendency of the estimated response functions. The responses were normalized to represent 100 basis points' (bps) worth of shocks. Accurate confidence intervals are calculated via a bootstrap procedure as in Kilian (1998), which accounts for the uncertainty in the factor estimation. One of the main advantages of the FAVAR approach is that IRFs can be constructed for any variable in the information set. Due to space constraints, we only report those that are relevant to the causal relations investigated.

We first estimate the effects of positive surprises in monetary and fiscal policy on a set of variables related to the financial sector. Specifically, we are interested in determining the responses of variables describing financial cycle development (housing prices, loans to the private non-financial sector, NPL ratio), the prudential behaviour of banks (loss provisions, risk-weighted assets), and bank resilience (capital surplus). The choice of variables describing financial cycle development is primarily motivated by Babecky et al. (2012), Reinhart and Rogoff (2013), and Laeven and Valencia (2010, 2013), who studied the early warning indicators of financial crises and determined that property prices, interest rates on loans, and volume of lending to the private sector are good information sources. We complement these variables with the official financial cycle index, computed and published by the Czech National Bank (see Plasil et al., 2015, for 
details on index construction). ${ }^{11}$ Details of financial cycle evolution in the Czech Republic are available in Appendix B.

\section{Transmission of fiscal and monetary policy-like shocks}

First, to see if the model captures relevant theoretical responses of the main macroeconomic variables to fiscal and monetary policy-like shocks, we show the response of real GDP, unemployment rate, inflation, and real effective exchange rate (Figure 1). Following monetary policy expansion, real economic activity eventually increases, which manifests itself in higher real GDP growth and a lower rate of unemployment. The annualized consumer price index exhibits a lagged increase after 3 to 4 quarters, which is in line with the targeting horizon of the CNB and largely coincides with previous empirical evidence (Borys et al., 2009). We document a minor price puzzle right after the shock, which may be linked to inflation undershooting in the post-crisis period. This explanation is supported by the fact that when using only the data up to 2012Q1 for estimation, this small price puzzle disappears.

Turning to the effects of fiscal expansion, we report a gradual increase in real GDP growth and a decrease in the rate of unemployment. However, while the immediate median reaction of GDP is positive, it gradually turns negative, suggesting only a marginal reaction which may be associated with a partial crowding-out effect. This was also found to be true in Franta (2012) and Ambrisko et al. (2015), who estimate fiscal policy transmission using Czech data as well. Like us, they also report an increased inflation rate following increased government expenditures, and a rather ambiguous response of the exchange rate.

\section{Figure 1 Fiscal and monetary policy transmission into the real economy}
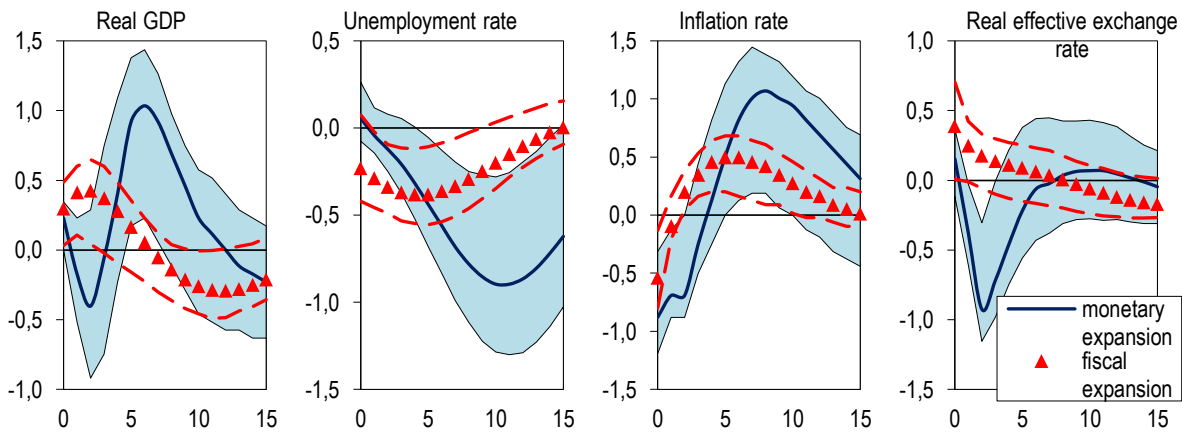

Notes: Median impulse responses are reported with $90 \%$ probability bands. The y-axis measures the strength of the variable's response in percentage points; the $x$-axis is in quarters after the shock. All variables except the rate of unemployment enter the model as annualized percentage growth.

\footnotetext{
${ }^{11}$ Note that we do not use the credit-to-GDP gap in any form to proxy for financial cycle development. Numerous studies have shown that it may yield incorrect information (Edge and Meisenzahl, 2011; Hamilton, 2017, to name a few). Gersl and Seidler (2011) have further shown that the credit-to-GDP gap is not an appropriate measure for converging economies, such as the Czech Republic.
} 
Second, we turn our attention to the responses of the financial sector-related set of variables (Figure 2). Following a relaxation of monetary policy, credit activity increases proportionally, which is not surprising. An increase in risk-weighted assets is the more likely outcome of an increased amount of loans to the private sector, but the results may also suggest a change in banks' portfolio structure towards riskier investments (a search-for-yield motive). Highly surprising, however, are the significant disproportions between short and medium term responses of residential property prices and the financial cycle index. These two variables are directly linked to financial cycle development. While they decrease mildly at first (i.e., a more stable financial sector), they eventually increase 4 to 5 quarters after the original shock, peaking at 7 to 8 quarters. We provide the following economic interpretation for the result:

In the short term, before economic agents are able to adjust their balance sheets, lower interest rates benefit financial system stability. First, by boosting aggregate demand, a monetary expansion increases household earnings and firms' profitability. Lower interest rates also decrease the debt service ratio in the short term; i.e., we document a positive impact of monetary policy on effective lending rates, which dominates a negative effect on debt-to-income ratios (in line with the conclusions of Hoffman and Peersman, 2017). This is also evident from the response of the NPL ratio, which declines right after the shock. In the medium term however, the effects of monetary expansion are likely to reverse, as we observe a gradual increase in residential property prices, the financial cycle index, the debt service ratio, and non-performing loans after 3 to 7 quarters from the shock's introduction. This is a natural outcome of the already-boosted demand for credit, but it also shows that monetary policy might eventually promote risk-taking behaviour in both households and banks. From a financial stability perspective, following a relaxation of monetary policy the loss provisions and capital surplus decrease, which indicates a decrease in banks' prudential behaviour and resilience to potential stressful events.

As concerns fiscal policy, its measures are also transmitted to the financial sector and affect our set of variables. Credit activity increases after the shock, suggesting that even fiscal expansion may increase the demand for credit, especially if economic agents believe that the fiscal expansion is of a relatively permanent nature and not merely a temporary measure. We do not find evidence supporting any kind of Ricardian behaviour among economic subjects. Judging from the increased residential property prices, we argue that the credit channel of fiscal policy operates through the housing market. The rise in credit may lead to a surge in demand for housing and contribute to the upward response of residential property prices. In this manner, fiscal expansion also temporarily improves economic agents' balance sheets because of the increasing value of collateral. This effect is borne out by the NPL ratio response, which decreases at impact. Our results generally confirm the views presented in Agnello and Sousa (2013), who show that government size matters in the estimation of the fiscal policy-asset price relationship, and that countries small in size (such as the Czech Republic) are more likely to avoid a credit shortage generated by increased government deficits. 
Figure 2 Fiscal and monetary policy pass-through into the financial sector
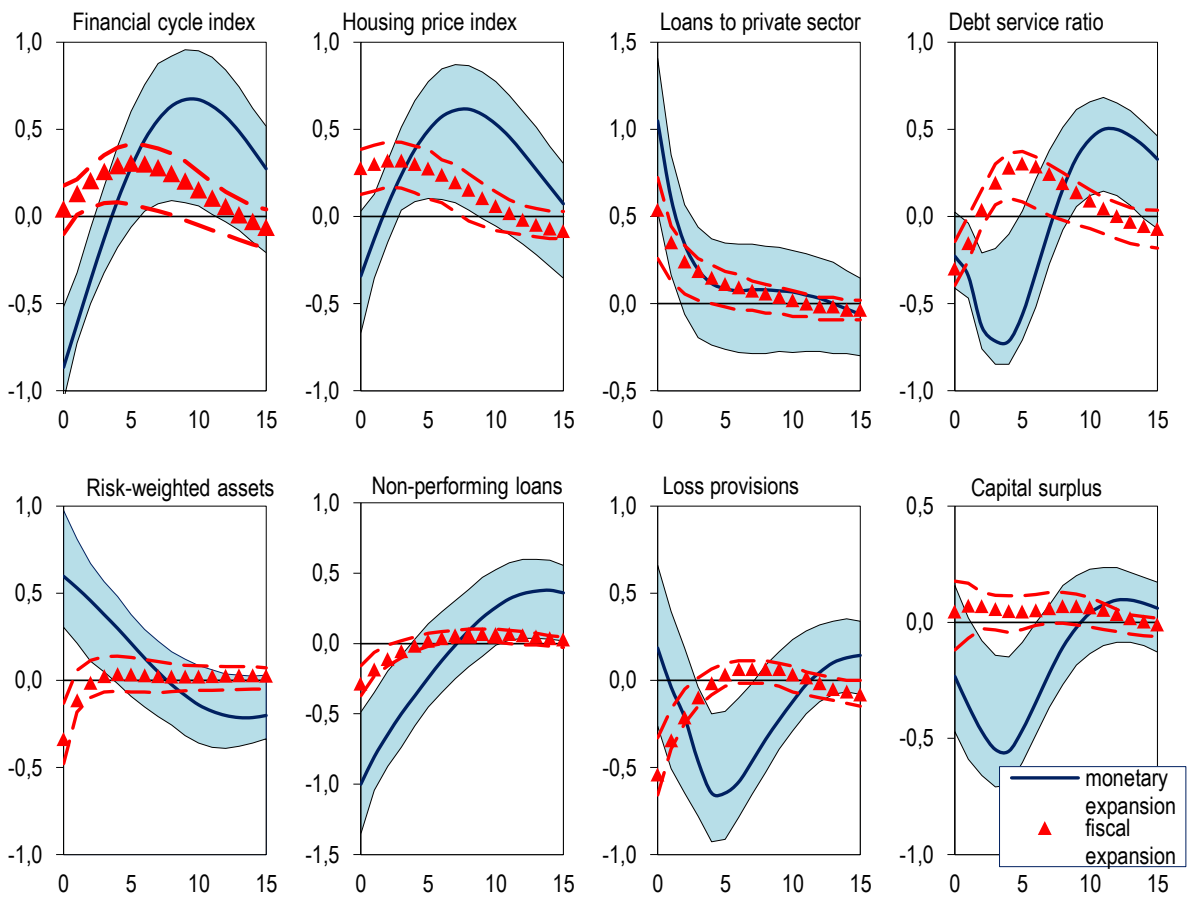

Notes: Median impulse responses are reported with $90 \%$ probability bands. The y-axis measures the strength of the variable's response in percentage points; the x-axis is quarters after the shock. All variables except the financial cycle index enter the model as annualized percentage growth.

Table 2 Cumulative impulse responses for fiscal and monetary policy shock

\begin{tabular}{c|ccc|ccc}
\hline \hline & \multicolumn{3}{|c|}{ Monetary expansion } & \multicolumn{3}{c}{ Fiscal expansion } \\
\hline \multirow{2}{*}{ period } & $1-4$ & $5-8$ & $9-12$ & $1-4$ & $5-8$ & $9-12$ \\
& -0.165 & 2.061 & 2.189 & 1.218 & 1.006 & \\
Housing price index & -0.494 & 1.366 & 2.609 & 0.635 & 1.175 & n. s. \\
Financial cycle index & -2.951 & -0.75 & 0.848 & -0.638 & 0.092 & \\
Non-performing loans & -1.918 & -1.671 & $1-437$ & -0.223 & 1.111 & \\
Debt service ratio & 2.189 & 0.354 & 0.268 & 1.314 & 0.426 & 0.111 \\
Loans to private sector & 1.963 & 0.689 & -0.426 & -0.447 & 0.116 & 0.084 \\
\hline Risk-weighted assets & & &
\end{tabular}

Notes: Cumulative responses for the first (1st to 4th quarter), second (5th to 8th quarter), and third (9th to 12th quarter) year after the shock; $n$. s. denotes response is not significant in the given period.

Table 2 provides a comparison of fiscal and monetary policy effects on financial variables related to financial stability. At first glance, we identify some key time-variations 
in the responses. While the monetary expansion seems to lower the risk of financial instability in the short term (within the first year), it promotes an increase in credit dynamics and might subsequently (if kept accommodative long enough) lower financial resilience. Fiscal expansion, on the other hand, influences credit dynamics and the related set of variables in the short term and then fades out. These results point towards an unfavourable policy mix: monetary expansion coupled with subsequent fiscal expansion. Let us consider one hypothetical scenario in the economy: ${ }^{12}$ The central bank relaxes its monetary policy and decreases interest rates, which should translate into increased economic activity and temporarily lower the risk of financial instability. This could create sufficient fiscal space for the government to support the monetary expansion by raising its spending. The already mounting effects of monetary expansion are now multiplied by the effects of fiscal expansion on asset prices and risk appetite. Under these conditions, macroprudential policy measures might not be sufficient to contain systemic risk build-ups.

Frait and Malovana (2017) recently confirmed that accommodative monetary policy contributes to a build-up of financial vulnerabilities. This means that a conflict may arise between monetary policy and macroprudential policy. Beyond this, we argue that monetary policy expansion might be further boosted by a subsequent fiscal expansion, and the present time-series evidence supports this claim. In light of our findings, macroprudential policy cannot view fiscal policy as Ricardian (passive), but must consider it similarly to how it views monetary policy. This obviously makes the coordination problem even more complex.

\section{What are the effects of systemic risk materialization?}

It is also relevant to ask to what extent the fiscal and monetary policy setting should take into account financial cycle development. To answer this question completely, we need to take into consideration not only the contribution of monetary and fiscal policies to systemic risk accumulation, but also the impact of systemic risk materialization on key macroeconomic variables (such as prices, output, fiscal sustainability, etc.) and financial sector variables. During this exercise, we simulate an increase in the NPL ratio, an indicator which generally increases during periods of financial stress due to the increase in the number of bankruptcies and delinquencies (numerator effect) and decrease in the dynamics of new loans granted (denominator effect). We henceforth refer to this innovation as a "systemic risk materialization shock".

Figure 3 shows that the materialization of systemic risk affects economic activity and variables associated with fiscal and monetary policy. It causes a substantial drop in economic activity, lasting over a year. Typical symptoms are declining real GDP, rising unemployment, and falling prices. The documented currency depreciation might be an outcome of two mechanisms: first, we might be picking up some of the effects of currency interventions by the CNB (from 2015 to 2017); and second, in response to deflationary pressures, the CNB significantly lowered its main policy rates, which would, under the uncovered interest rate parity rule, lower the REER as well.

\footnotetext{
${ }^{12}$ In fact, the analysis of fiscal-monetary policy interaction presented in Figure 1D in the Appendix shows that this scenario is plausible.
} 
Figure 3 Systemic risk materialization and real economic activity
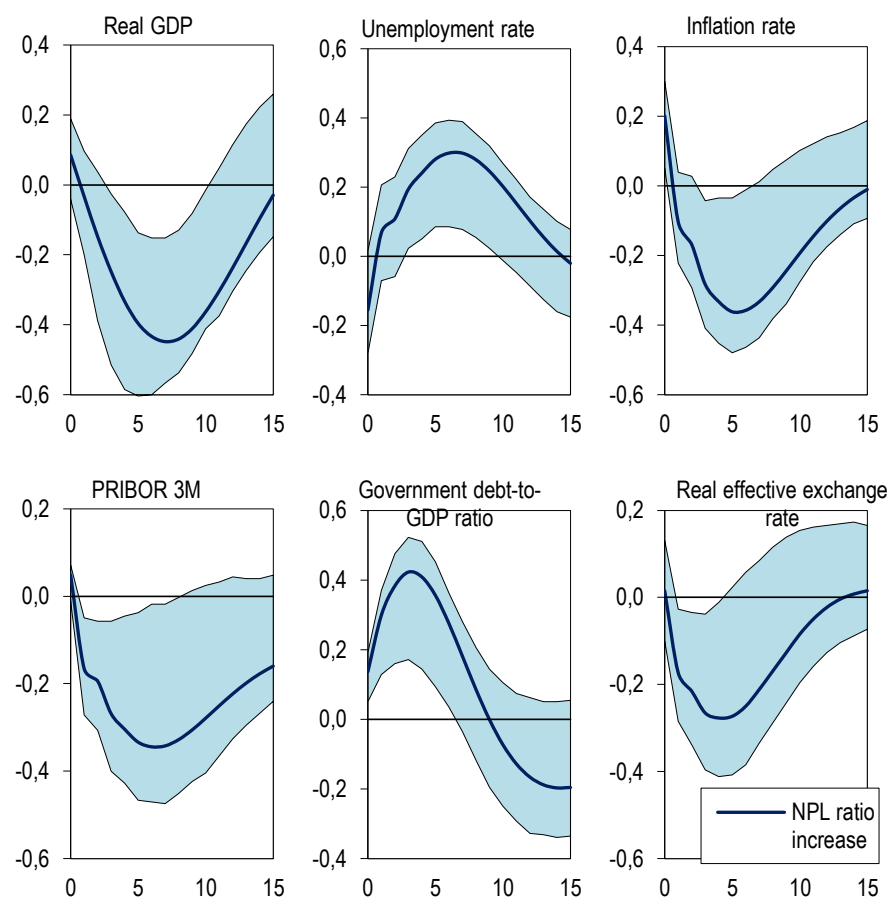

Notes: Median impulse responses are reported with $90 \%$ probability bands. The y-axis measures the strength of the variable's response in percentage points; the $x$-axis is in quarters after the shock. All variables except the rate of unemployment and PRIBOR $3 M$ enter the model as annualized percentage growth.

Further, systemic risk materialization may also manifest itself in the economy's fiscal position and sovereign risk, as it influences both government revenues and expenditures and debt service costs. This stems from decreased economic activity, which lowers revenues from taxes. Regarding government expenditure, we may expect it to increase in the form of government support packages reacting to the ailing economy. Subsequently, because of the worsened primary budgetary balance and decreased GDP, we document a substantial increase in the debt-to-GDP ratio. Overall, we find some evidence of a non-negligible deterioration in public finances following systemic risk materialization. In general, we confirm the significantly negative effect of systemic risk materialization and its rather quick transmission into the real economy and to variables associated with fiscal and monetary policy. 
Figure 4 Systemic risk materialization, policy responses and the financial sector
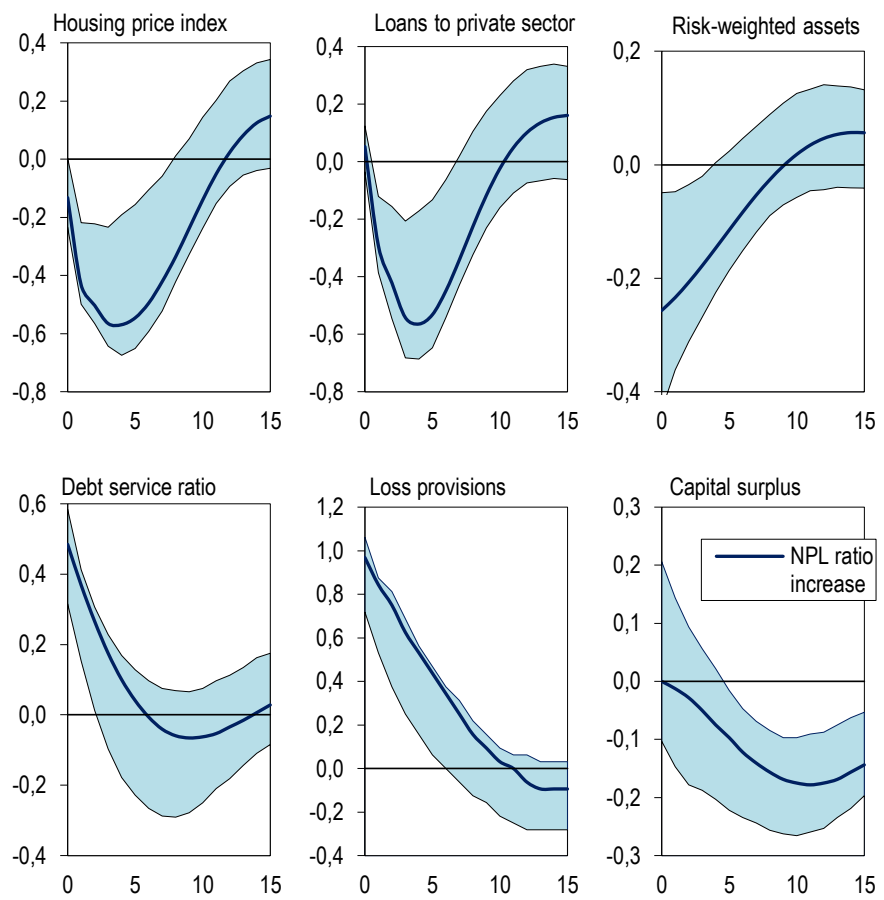

Notes: Median impulse responses are reported with $90 \%$ probability bands. The y-axis measures the strength of the variable's response in percentage points; the $x$-axis is in quarters after the shock. All variables enter the model as annualized percentage growth.

Figure 4 gives indications as to the causes behind the systemic risk materialization in the financial sector: With the decreased ability of economic agents to repay their loans, we document a rather sharp decline in both credit dynamics and housing prices. This adverse market situation affects mainly commercial banks, which collectively become much more risk-averse, changing their portfolios in favor of less risky assets (in practice, this would manifest as increased exposure to the government and central bank). This is a simple signaling strategy wherein banks strive to present themselves as stable to decrease the cost of additional capital, which, due to the crisis, generally increases. In spite of decreasing risk-weighted assets (outcome of the above-mentioned portfolio cleansing), capital surplus significantly decreases. This might also be achieved by simply increasing the capital requirements. Materialization of systemic risk increases loss provisions and risk costs, which represent a significant component of the interest rate on loans. Growth of interest rates on loans to the private sector increases the debt service ratio and might lead to further deterioration of the loan portfolio.

\section{Conclusions}

We explore situations in which fiscal, monetary, and financial stability may interact, and contribute to the discussion about the related policies' coordination and potential 
conflicts. We highlight the need to take into consideration both fiscal and monetary policy, as they may both affect asset prices and credit dynamics and contribute to systemic risk accumulation and therefore influence financial cycle amplitude. For this purpose, we construct a FAVAR model to capture the policy interplay in a data-rich environment. The FAVAR model helps ensure that the estimated impulse responses are invariant with respect to extensions of the information set - an issue that often plagues impulse response results.

The presented model enables us to identify several patterns. First, loose economic policies have a positive impact on financial stability in the short term, but this effect may reverse in the medium term. In greater detail, we find that fiscal and monetary policylike shocks impact the economy and financial sector differently. While fiscal expansion influences credit dynamics and the related set of financial sector variables in the short term and then quickly fades out, monetary expansion seems to benefit financial stability at first, but its effects turn negative in the medium term. This somewhat complicates the answers to the first two research questions presented in the introduction: For the first question, loose economic policies might indeed benefit financial stability in the short term, but (if kept accommodative long enough) they will eventually work in the opposite direction, towards instability. For the second, yes, fiscal and monetary policy shocks impact the financial sector differently. We highlight the need to consider the full policy mix (fiscal and monetary policy effects) when formulating appropriate policy measures. Regarding our third research question, we find that financial imbalances (systemic risk materialization) cause losses in output, damage public finances, and trigger deflationary pressures. Furthermore, systemic risk materialization leads to increases in the debt service ratio and might lead to further deterioration of the loan portfolio.

Overall, our results confirm the need to discuss and coordinate changes in economic policy to avoid potential conflict situations and surprises in the market. Going beyond existing research, we also provide time-series evidence showing that macroprudential policy cannot view fiscal policy as Ricardian (passive), but must consider it similarly to how it views monetary policy. Further, our finding that both fiscal and monetary policy may be transmitted into the financial sector and influence the risk-taking behavior of economic agents provides support for countercyclical fiscal and monetary policy. Therefore, we make several policy recommendations that may decrease the procyclical character of economic policy and mitigate possible conflict situations at low implementation cost:

In the fiscal policy area, we believe implementing a fiscal rule to restrict the procyclical character of public finances and stabilize government debt over the long term would be beneficial. However, as the Bank for International Settlements (2016) states, it is important to augment the fiscal rule with a proper automatic stabilization scheme, and apply it ex ante when certain economic conditions are met. Further, Borio et al. (2013) recommend including information about financial cycle development into the potential product and output gap estimation. Another possibility for mitigating the unwanted fiscal policy procyclicality associated with systemic risk build-up would be to partially adjust the taxation system in order to limit the growth of certain types of credit. Given the procyclical development of residential property prices and loans to the private sector, 
it would be beneficial to limit mortgage tax relief (see Andrews et al., 2011). ${ }^{13}$ The European Commission (2015) has encouraged Member States to ensure that tax systems do not encourage household debt. Lombardi et al. (2017) give evidence of the negative impact of high household indebtedness on GDP growth over the long term. There are possibilities to limit the impact of sovereign risk on the banking sector. The Czech National Bank was among the first to implement methods for public finance stress testing with special capital requirements on banks with higher sovereign default risk on government bonds (CNB, 2016).

The impact of monetary policy actions on financial stability may be partially mitigated by incorporating residential property prices in the targeted consumer price index or by using a broader index (Hampl and Havranek, 2017, describe CPIH on the case of the Czech Republic) as a supplementary indicator for monetary policy decisions. There are also other, more controversial propositions for mitigating the procyclical character of monetary policy. Borio (2016) suggests the use of an augmented Taylor rule, in which the monetary authority should respond not only to the inflation gap but also to some defined financial stability gap, and state that a monetary policy rule that takes financial developments into account could help reduce the financial cycle, leading to higher output in the long run.

Acknowledgements: We would like to thank Jaromir Baxa, Ales Melecky and two anonymous referees for their helpful comments on earlier versions of this paper. We would also like to thank the seminar participants at the 2016 Conference on Currency, Banking, and International Finance, the 2016 European Financial Systems Conference, Technical University of Ostrava, and the Slovak Academy of Sciences for their comments. The views and opinions expressed herein are those of the authors and do not represent the views of their institutions. All errors and omissions remain entirely the fault of the authors.

Funding: This work was supported by the 2017 research grant (SP2017/110) from Technical University of Ostrava and the Czech Science Agency, grant Anti-cyclical policies and external equilibrium in a model of inflation targeting, No. 18-12340S.

Disclosure statement: No potential conflict of interest was reported by the authors.

\section{References}

AASTVEIT, K. A. (2013). Oil price shocks and monetary policy in a data-rich environment. Working paper series 10/2013, Norges Bank (Central Bank of Norway).

AASTVEIT, K., FURLANETTO, F., \& LORIA, F. (2017). Has the fed responded to house and stock prices? A time-varying analysis. Working paper series 01/2017, Norges Bank (Central Bank of Norway).

ABBATE A., \& THALER, D. (2015). Monetary policy and the asset risk-taking channel. Discussion paper 48/2015, Deutsche Bundesbank.

\footnotetext{
${ }^{13}$ Bank for International Settlements (2016) illustrates the relationship between mortgage tax relief and household debt.
} 
ADRIAN, T., \& LIANG, N. (2016). Monetary policy, financial conditions, and financial stability. Staff report 690, Federal Reserve Bank of New York.

AGNELLO, L., \& SOUSA, R. M. (2009). The determinants of public deficit volatility. Working paper 1042, European Central Bank.

AGNELLO, L., \& SOUSA, R. M. (2013). Fiscal policy and asset prices. Bulletin of Economic Research, 65(2), 154-177. DOI: 10.1111/j.0307-3378.2011.00420.x

AMBRISKO, R., BABECKY, J., RYSANEK, J., \& VALENTA, V. (2015). Assessing the impact of fiscal measures on the Czech economy. Economic Modelling, 55(1), 350357. DOI: $10.1016 /$ j.econmod.2014.07.021

ANDREWS, D., CALDERA SÁNCHEZ, A., \& JOHANSSON, A. (2011). Housing markets and structural policies in OECD countries. Economics department working papers 836, OECD.

ANGELONI, I., FAIA, E., \& LO DUCA, M. (2017). Monetary policy and risk taking. Journal of Economic Dynamics \& Control, 52, 285-307. DOI: 10.1016/j.jedc.2014.12.001

ARI, A. (2016). Sovereign risk and bank risk-taking. Working paper series 1894/2016, European Central Bank.

AYDIN, B., \& VOLKAN, E. (2011). Incorporating financial stability in inflation targeting framework. Working paper 11/224, International Monetary Fund.

BABECKY, J., HAVRANEK, T., MATEJU, J., RUSNAK, M., SMIDOVA, K., \& VASICEK, B. (2013). Leading indicators of crisis incidence: evidence from developed countries. Journal of International Money and Finance, 35, 1-19. DOI:

10.1016/j.jimonfin.2013.01.001

BERNANKE, B., BOIVIN, J., \& ELIAZS, P. (2005). Measuring the effects of monetary policy: a factor-augmented vector autoregressive (FAVAR) approach. The Quarterly Journal of Economics, 120 (1), 387-422.

BIANCHI, F., \& ILUT, C. (2017). Monetary/fiscal policy mix and agent's beliefs. Review of Economic Dynamics, 26, 113-139. DOI: 10.1016/j.red.2017.02.011

BANK FOR INTERNATIONAL SETTLEMENTS (2016). Towards a financial stability-oriented fiscal policy. Basel: Bank for International Settlements.

BLANCHARD, O., \& PEROTTI, R. (2002). An empirical characterization of the dynamic effects of changes in government spending and taxes on output. The Quarterly Journal of Economics, 117(4), 1329-1368. DOI: 10.1162/003355302320935043

BORIO, C. (2014a). The financial cycle and macroeconomics: what have we learnt? Journal of Banking \& Finance, 45(1), 182-98. DOI: 10.1016/j.jbankfin.2013.07.031

BORIO, C. (2014b). The international monetary and financial system: its Achilles heel and what to do about it. Working Paper 456, Bank for International Settlements.

BORIO, C. (2016). Revisiting three intellectual pillars of monetary policy. Cato Journal, 36(2), 213-238. 
BORIO, C. (2017). Secular stagnation or financial cycle drag? Business Economics, 52(2), 87-98. DOI: $10.1057 / \mathrm{s} 11369-017-0035-3$

BORIO, C., \& Lowe, P. (2002). Asset prices, financial and monetary stability: exploring the nexus. Working paper 114, Bank for International Settlements.

BORIO, C., DISYATAT, P., \& JUSELIUS, M. (2013). Rethinking potential output: embedding information about the financial cycle. Working Paper 404, Bank for International Settlements.

BORIO, C., KHARROUBI, E., UPPER, Ch., \& ZAMPOLLI, F. (2015). Labour reallocation and productivity dynamics: financial causes, real consequences. Working Paper 534, Bank for International Settlements.

BORIO, C., \& ZHU, H. (2012). Capital regulation, risk-taking and monetary policy: a missing link in the transmission mechanism? Journal of Financial Stability, 8(4), 236251. DOI. 10.1016/j.jfs.2011.12.003

BORYS, M., FRANTA, M., \& HORVATH, R. (2009). The effects of monetary policy in the Czech Republic: an empirical study. Empirica, 36(1), 419-443. DOI: 10.1007/s10663-009-9102-y

CARLSTROM, Ch, FUERST, T., \& PAUSTIAN, M. (2010). Optimal monetary policy in a model with agency costs. Journal of Money, Credit and Banking, 42(6), 37-70. DOI: 10.1111/j.1538-4616.2010.00329.x

DEEV, O., \& HODULA, M. (2016). Sovereign default risk and state-owned bank fragility in emerging markets: evidence from China and Russia. Post-Communist Economies, 28(2), 232-248. DOI: 10.1080/14631377.2016.1164438

DREHMANN, M., \& JUSELIUS, M. (2012). Do debt service costs affect macroeconomic and financial stability? BIS Quaterly Review, September 2012, 21-35.

DREHMANN, M., BORIO, C., \& TSATSARONIS, K. (2012). Characterizing the financial cycle: don't lose sight of the medium term! Working Paper 380, Bank for International Settlements.

DUNGEY, M., \& FRY, R. (2009). The identification of fiscal and monetary policy in a structural VAR. Economic Modelling, 26(6), 1147-1160. DOI:

10.1016/j.econmod.2009.05.001

EDGE, R. M., \& MEISENZAHL, R. R. (2011). The unreliability of Credit-to-GDP ratio gaps in real time: implications for countercyclical capital buffers. International Journal of Central Banking, 7(4), 261-298.

EICKMEIER, S. \& HOFMANN, B. (2013). Monetary policy, housing booms and financial (im)balances. Macroeconomic Dynamics, 17(4), 830-860. DOI: 10.1017/S1365100511000721

ESCHENBACH, F., \& SCHUNKNECHT, L. (2004). The fiscal costs of financial instability revisited. Economic Policy, 14(1), 313-346.

ESRB (2016). Macroprudential policy beyond banking: an ESRB strategy paper. Frankfurt am Main: European System Risk Board. 
FILARDO, A., \& RUNGCHAROENKITKUL, P. (2016). A quantitative case for leaning against the wind. Working Paper 594, Bank for International Settlements.

FORNI, M., \& GAMBETTI, L. (2010). The dynamic effects of monetary policy: A structural factor model approach. Journal of Monetary Economics, 57(1), 203-216. DOI: $10.1016 /$ j.jmoneco.2009.11.009

FRANTA, M. (2012). Macroeconomic effects of fiscal policy in the Czech Republic: evidence based on various identification approaches in a VAR framework. Working Paper 13/2012, Czech National Bank.

GALATI, G. \& MOESSNER, R. (2013) Macroprudential policy - a literature review. Journal of Economic Surveys 27(5), 846-878.

GALÍ, J., \& GAMBETTI, L. (2015) The effects of monetary policy on stock market bubbles: some evidence. American Economic Journal: Macroeconomics, 7(1), 233-57.

GERSL, A., \& SEIDLER, J. (2015). Countercyclical capital buffers and Credit-to-GDP gaps: simulation for central, eastern, and southeastern Europe. Eastern European Economics, 53(6), 439-465. DOI: 10.1080/00128775.2015.1102602

GILBERT C., LEVIEUGEA, G., \& POPESCU, A. (2018). Monetary policy and longrun systemic risk-taking. Journal of Economic Dynamics and Control, 86, 165-184. DOI: $\underline{10.1016 / j . j e d c .2017 .11 .001}$

GOODHART, C. (2001). What Weight Should Be Given to Asset Prices in the Measurement of Inflation? The Economic Journal, 111(472), 335-356. DOI: 10.1111/1468$\underline{0297.00634}$

GRAMLICH, D., Miller, G. L., OET, M. V., \& ONG, S. J. (2010). Early warning systems for systemic banking risk: critical review and modeling implications. Banks and Bank Systems, 5(2), 199-211.

HALLETT, A. H., \& LEWIS, J. (2008). European fiscal discipline before and after EMU: crash diet or permanent weight loss? Macroeconomic Dynamics, 12(3), 404-24. DOI: $10.1017 / \mathrm{S} 1365100507070204$

HAMILTON, J. D. (2017, in press). Why you should never use the Hodrick-Prescott filter. Review of Economics and Statistics. DOI: 10.1162/REST_a_00706

HAMPL, M., \& HAVRANEK, T. (2017). Should inflation measures used by central banks incorporate house prices? the Czech National Bank's approach. Research and Policy Note 1/2017, Czech National Bank.

HAUG, A., JEDRZEJOWIC, T., \& SZNAJDERSKA, A. (2013). Combining monetary and fiscal policy in an SVAR for a small open economy. Working Paper 168, Narodowy Bank Polski (Central bank of Poland).

HODULA, M., \& PFEIFER, L. (2018). The impact of credit booms and economic policy on labour productivity: a sectoral analysis. Acta VŠFS, 12(1), 10-42.

HOFFMAN, B., \& PEERSMAN, G. (2017). Is there a debt service channel of monetary transmission? BIS Quarterly Review, December 2017, 23-37. 
IMF (2015). Monetary policy and financial stability. Washington: International Monetary Fund.

IWATA, Y. (2013). Two fiscal policy puzzles revisited: new evidence and an explanation. Journal of International Money and Finance, 33(C), 188-207. DOI: 10.1016/j.jimonfin.2012.11.015

JUSELIUS, M., BORIO, C., DISYATAT, P., \& DREHMANN, M. (2017). Monetary policy, the financial cycle, and ultra-low interest rates. International Journal of Central Banking, 13(3), 55-90.

KILIAN, L. (1988). Small-sample confidence intervals for impulse response functions. Review of Economics and Statistics, 80 (2), 218-230. DOI: $\underline{10.1162 / 003465398557465}$

KUTTNER, K. N. (2013). Low interest rates and housing bubbles: still no smoking gun. In Douglas D. Evanoff et al. (ed.), The Role of Central Banks in Financial Stability, pp. 218-230. Singapore: World Scientific Publishing.

LAEVEN, L., \& VALENCIA, F. (2010). Resolution of banking crises: the good, the bad, and the ugly. Working Paper 146, International Monetary Fund.

LAEVEN, L., \& VALENCIA, F. (2013). Systemic banking crises database. IMF Economic Review, 61(2), 225-270. DOI: 10.1057/imfer.2013.12

LAGANA, G., \& SGRO, P. M. (2011). A factor-augmented VAR approach: the effect of a rise in the US personal income tax rate on the US and Canada. Economic Modelling, 28(3), 1163-1169. DOI: 10.1016/j.econmod.2010.12.007

LAINA, P., NYHOLM, J., \& SARLIN, P. (2015). Leading Indicators of Systemic Banking Crises: Finland in a panel of EU countries. Working paper 1758, European Central Bank.

LEEPER, E. M. (1991). Equilibria under active and passive monetary policies. Journal of Monetary Economics, 27(1), 129-147. DOI: 10.1016/0304-3932(91)90007-B

LIBICH, J. (2017). Unpleasant monetarist arithmetic: macroprudential edition. Working Paper 2017-40, Centre for Applied Macroeconomic Analysis.

LOMBARDI, M., MOHANTY, M., \& SHIM, I. (2017). The real effects of household debt in the short and long run. Working Paper 607, Bank for International Settlements.

MALOVANÁ, S., \& FRAIT, J. (2017). Monetary policy and macroprudential policy: rivals or teammates? Journal of Financial Stability, 32, 1-16. 10.1016/j.jfs.2017.08.004

MOUNTFORD, A., \& UHLIG, H. (2009). What are the effects of fiscal policy shocks? Journal of Applied Econometrics, 24(6), 960-992. 10.1002/jae.1079

MUSCATELLI, V.A., TIRELLI, P., \& TRECROCI, C. (2004). Fiscal and monetary policy interactions: empirical evidence and optimal policy using a structural New Keynesian model. Journal of Macroeconomics, 26, 257-280. DOI: 10.1016/j.jmacro.2003.11.014

OBSTFELD, M., \& ROGOFF, R. (2009). Global imbalances and the financial crisis: Products of common causes. Econometrics laboratory. Discussion Paper 7606, Centre for Economic Policy Research. 
ORPHANIDES, A. (2017). The fiscal-monetary policy mix in the euro area: challenges at the zero lower bound. Discussion Paper 060, European Commission.

PAUL, P. (2018). The Time-Varying Effect of Monetary Policy on Asset Prices. Working Paper 2017-09, Federal Reserve Bank of San Francisco.

PLASIL M., KONECNY, T., SEIDLER, J., \& HLAVAC, P. (2015). In the quest of measuring the financial cycle. Working Paper 5-2015, Czech National Bank.

REINHART, C. M., \& ROGOFF, S. K. (2013). Banking crises: an equal opportunity menace. Journal of Banking \& Finance, 37(11), 4557-4573. DOI: 10.1016/j.jbankfin.2013.03.005

ROSSI, B., \& ZUBAIRY, S. (2011). What is the importance of monetary and fiscal shocks in explaining U.S. macroeconomic fluctuations? Journal of Money, Credit and Banking, 43(6), 1247-1270. DOI: 10.1111/j.1538-4616.2011.00424.X

SARGENT, T. J., \& WALLACE, N. (1991). Some unpleasant monetarist arithmetic. Federal Reserve Bank of Minneapolis Quarterly Review, 5(3), 1-17.

SCHUKNECHT, L., von HAGEN, J., \& WOLSWIJK G. (2009). Government risk premiums in the bond market: EMU and Canada. European Journal of Political Economy, 25, 371-84. DOI: 10.1016/j.ejpoleco.2009.02.004

SMETS, F. (2014). Financial stability and monetary policy: how closely interlinked? International Journal of Central Banking, 10(2), 263-300.

STOCK, J. H., \& WATSON, M. W. (2002). Forecasting using principal components from a large number of predictors. Journal of the American Statistical Association, 97(460), 1167-1179. DOI: $\underline{10.1198 / 016214502388618960}$

SVENSSON, L. E. (2016). Cost-benefit analysis of leaning against the wind: Are costs larger with less effective macroprudential policy? Working Paper 16/3, International Monetary Fund.

TAYLOR, J. B. (2009). Economic policy and the financial crisis: an empirical analysis of what went wrong. Critical Review. A Journal of Politics and Society, 21, 341-364.

TUZCUOGLU, K., \& HOKE, S. H. (2016). Interpreting the latent dynamic factors by threshold FAVAR model. Working Paper 622, Bank of England.

UEDA, K., \& VALENCIA, F. (2014). Central bank independence and macro-prudential regulation. Economics Letters, 125(2), 327-330. DOI: 10.1016/j.econlet.2013.12.038

WOODFORD, M. (1996). Control of the public debt: A requirement for price stability? Working Paper 5684, National Bureau of Economic Research.

WOODFORD, M. (2011). Simple analytics of the government expenditure multiplier. American Economic Journal: Macroeconomics, 3(1), 1-35. 


\section{Appendix}

\section{A. Data description}

\section{Table 1. Data description and sources}

\begin{tabular}{|c|c|c|c|c|c|c|}
\hline Group & No. & Series description & Unit & Source & TC & S/F \\
\hline \multirow{33}{*}{ 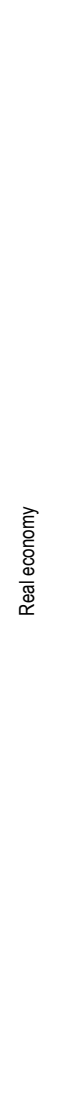 } & 1 & Industrial production index, industry total & $2010=100$ & CSO -Industry, energy & $2^{*}$ & $S$ \\
\hline & 2 & Industrial production index, mining and quarrying & $2010=100$ & CSO -Industry, energy & $2^{*}$ & $\mathrm{~s}$ \\
\hline & 3 & Industrial production index, manufacturing & $2010=100$ & CSO -Industry, energy & $2^{*}$ & $\mathrm{~s}$ \\
\hline & 4 & Industrial production index, electricity, gas, steam and air conditioning & $2010=100$ & CSO -Industry, energy & $2^{*}$ & $S$ \\
\hline & 5 & Sales from industrial activity, industry total & $2010=100$ & CSO -Industry, energy & $2^{*}$ & $S$ \\
\hline & 6 & Sales from industrial activity, mining and quarrying & $2010=100$ & CSO -Industry, energy & $2^{*}$ & $\mathrm{~s}$ \\
\hline & 7 & Sales from industrial activity, manufacturing & $2010=100$ & CSO -Industry, energy & $2^{*}$ & $S$ \\
\hline & 8 & Sales from industrial activity, electricity, gas, steam and air conditioning & $2010=100$ & CSO -Industry, energy & $2^{*}$ & $S$ \\
\hline & 9 & Direct export sales, industry total & $2010=100$ & CSO -Industry, energy & $2^{*}$ & $S$ \\
\hline & 10 & Direct export sales, mining and quarrying & $2010=100$ & CSO -Industry, energy & $2^{*}$ & $\mathrm{~s}$ \\
\hline & 11 & Direct export sales, manufacturing & $2010=100$ & CSO -Industry, energy & $2^{*}$ & $\mathrm{~s}$ \\
\hline & 12 & Domestic sales, industry total & $2010=100$ & CSO -Industry, energy & $2^{*}$ & S \\
\hline & 13 & Domestic sales, mining and quarrying & $2010=100$ & CSO -Industry, energy & $2^{*}$ & s \\
\hline & 14 & Domestic sales, manufacturing & $2010=100$ & CSO -Industry, energy & $2^{*}$ & $\mathrm{~s}$ \\
\hline & 15 & Domestic sales, electricity, gas, steam and air conditioning supply & $2010=100$ & CSO -Industry, energy & $2^{*}$ & S \\
\hline & 16 & New industrial orders, industry total & $2010=100$ & CSO -Industry, energy & $2^{*}$ & s \\
\hline & 17 & Non-domestic new orders & $2010=100$ & CSO -Industry, energy & $2^{*}$ & S \\
\hline & 18 & Domestic new orders & $2010=100$ & CSO -Industry, energy & $2^{*}$ & s \\
\hline & 19 & Construction production index & $2010=100$ & CSO - Construction & $2^{*}$ & $\mathrm{~s}$ \\
\hline & 20 & House price index, buildings & $2010=100$ & CSO - Construction & $2^{*}$ & s \\
\hline & 21 & House price index, civil engineering works & $2010=100$ & CSO - Construction & $2^{*}$ & s \\
\hline & 22 & Retail trade receipts & $2010=100$ & CNB, ARAD & $2^{*}$ & S \\
\hline & 23 & Gross domestic product, market prices & Millions CZK & CSO - GDP & $2^{*}$ & S \\
\hline & 24 & GDP deflator & $2010=100$ & CNB, ARAD & $2^{*}$ & $\mathrm{~s}$ \\
\hline & 25 & Final consumption expenditures, total, current prices & Millions CZK & CSO - GDP & $2^{*}$ & S \\
\hline & 26 & Final consumption expenditures, households, current prices & Millions CZK & CSO - GDP & $2^{*}$ & S \\
\hline & 27 & Final consumption expenditures, government, current prices & Millions CZK & CSO - GDP & $2^{*}$ & $\mathrm{~s}$ \\
\hline & 28 & Final consumption expenditures, non-profit organisations, current prices & Millions CZK & CSO - GDP & $2^{*}$ & S \\
\hline & 29 & Gross capital formation, total, current prices & Millions CZK & CSO - GDP & $2^{*}$ & $\mathrm{~s}$ \\
\hline & 30 & Export, current prices & Millions CZK & CSO - GDP & $2^{*}$ & S \\
\hline & 31 & Import, current prices & Millions CZK & CSO - GDP & $2^{*}$ & S \\
\hline & 32 & Real gross domestic income & Millions CZK & CSO - GDP & $2^{*}$ & S \\
\hline & 33 & Debt service ratios for the private non-financial sector & $\%$ & BIS database & 2 & S \\
\hline \multirow{17}{*}{ 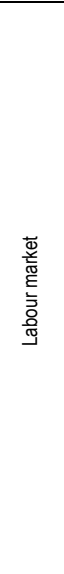 } & 34 & Industry total, average number of persons employed (ANPE) & no. of persons & CSO -Industry, energy & $2^{*}$ & S \\
\hline & 35 & Industry, mining and quarrying, ANPE & no. of persons & CSO -Industry, energy & $2^{*}$ & S \\
\hline & 36 & Industry, manufacturing, ANPE & no. of persons & CSO -Industry, energy & $2^{*}$ & $\mathrm{~s}$ \\
\hline & 37 & Industry, electricity, gas, steam and air conditioning supply, ANPE & no. of persons & CSO -Industry, energy & $2^{*}$ & S \\
\hline & 38 & Industry total, average gross nominal wage (AGNW) & CZK per person & CSO -Industry, energy & $2^{*}$ & s \\
\hline & 39 & Industry, mining and quarrying, AGNW & CZK per person & CSO -Industry, energy & $2^{*}$ & $\mathrm{~s}$ \\
\hline & 40 & Industry, manufacturing, AGNW & CZK per person & CSO -Industry, energy & $2^{*}$ & S \\
\hline & 41 & Industry, electricity, gas, steam and air conditioning supply, AAGNWNPE & CZK per person & CSO -Industry, energy & $2^{*}$ & s \\
\hline & 42 & Construction total, average number of persons employed (ANPE) & no. of persons & CSO - Construction & $2^{*}$ & S \\
\hline & 43 & Construction total, average gross nominal wage (AGNW) & CZK per person & CSO - Construction & $2^{*}$ & s \\
\hline & 44 & Employees total, hours worked & thousand hours & CSO - GDP & $2^{*}$ & $\mathrm{~s}$ \\
\hline & 45 & Employees, Agriculture, forestry and fishing & thousand hours & CSO - GDP & $2^{*}$ & S \\
\hline & 46 & Employees, Manufacturing, mining and quarrying and other industry & thousand hours & CSO - GDP & $2^{*}$ & s \\
\hline & 47 & Employees, Construction & thousand hours & CSO - GDP & $2^{*}$ & $\mathrm{~s}$ \\
\hline & 48 & Employees, Trade, transportation, accommodation and food service & thousand hours & CSO - GDP & $2^{*}$ & S \\
\hline & 49 & Employees, Public administration, education, health and social work & thousand hours & CSO - GDP & $2^{*}$ & S \\
\hline & 50 & General unemployment rate of the aged 15 to 64 years & $\%$ & CNB, ARAD & $1^{*}$ & s \\
\hline
\end{tabular}


Volume 18, Issue 3, 2018

\begin{tabular}{|c|c|c|c|c|c|c|}
\hline & 51 & Job Vacancies & thousand & CNB, ARAD & $2^{*}$ & s \\
\hline & 52 & Unplaced job seekers & thousand & CNB, ARAD & $2^{*}$ & S \\
\hline & 53 & Government debt, total & Millions CZK & CSO - Government & $2^{*}$ & $\mathrm{~s}$ \\
\hline & 54 & Debt securities, total & Millions CZK & CSO - Government & $2^{*}$ & S \\
\hline & 55 & Debt securities, short-term & Millions CZK & CSO - Government & $2^{*}$ & $\mathrm{~s}$ \\
\hline & 56 & Debt securities, long-term & Millions CZK & CSO-Government & $2^{*}$ & $S$ \\
\hline$\stackrel{\bar{E}}{E}$ & 57 & Government loans, total & Millions CZK & CSO-Government & $2^{*}$ & S \\
\hline 竧 & 58 & Government loans, short-term & Millions CZK & CSO-Government & $2^{*}$ & $S$ \\
\hline & 59 & Government loans, long-term & Millions CZK & CSO - Government & $2^{*}$ & S \\
\hline & 60 & Debt interests payed & Millions CZK & CSO-Government & $2^{*}$ & $S$ \\
\hline & 61 & Government expenditures, total & Millions CZK & CSO-Government & $2^{*}$ & S \\
\hline & 62 & Government revenue, total & Millions CZK & CSO - Government & $2^{*}$ & $\mathrm{~s}$ \\
\hline & 63 & Consumer Price Index (CPI), total & $2015=100$ & CNB, ARAD & $2^{*}$ & $S$ \\
\hline & 64 & $\mathrm{CPI}$, food and non-alcoholic beverages & $2015=100$ & CSO - Prices & $2^{*}$ & s \\
\hline & 65 & $\mathrm{CPI}$, alcoholic beverages, tobacco & $2015=100$ & CSO - Prices & $2^{*}$ & S \\
\hline & 66 & $\mathrm{CPI}$, clothing and footwear & $2015=100$ & CSO - Prices & $2^{*}$ & S \\
\hline & 67 & $\mathrm{CPI}$, housing, water, electricity, gas and other fuels & $2015=100$ & CSO - Prices & $2^{*}$ & S \\
\hline & 68 & $\mathrm{CPI}$, furnishings, household equipment, routine maintenance & $2015=100$ & CSO - Prices & $2^{*}$ & $\mathrm{~s}$ \\
\hline & 69 & $\mathrm{CPI}$, health & $2015=100$ & CSO - Prices & $2^{*}$ & S \\
\hline$\stackrel{\infty}{c}$ & 70 & $\mathrm{CPI}$, transport & $2015=100$ & CSO - Prices & $2^{*}$ & S \\
\hline 曾 & 71 & $\mathrm{CPI}$, communications & $2015=100$ & CSO - Prices & $2^{*}$ & S \\
\hline$\frac{\bar{d}}{x}$ & 72 & $\mathrm{CPI}$, recreation and culture & $2015=100$ & CSO - Prices & $2^{*}$ & $S$ \\
\hline$\stackrel{\Phi}{ \pm}$ & 73 & $\mathrm{CPI}$, education & $2015=100$ & CSO - Prices & $2^{*}$ & $S$ \\
\hline$\frac{\overline{2}}{c}$ & 74 & $\mathrm{CPI}$, restaurants and hotels & $2015=100$ & CSO - Prices & $2^{*}$ & S \\
\hline $\begin{array}{l}\text { T⿱乛龰 } \\
0 \\
0 \\
0\end{array}$ & 75 & $\mathrm{CPI}$, miscellaneous goods and services & $2015=100$ & CSO-Prices & $2^{*}$ & S \\
\hline & 76 & Industrial Producer Prices (IPP), total & $2015=100$ & CSO - Prices & $2^{*}$ & S \\
\hline & 77 & IPP, mining and quarrying & $2015=100$ & CSO - Prices & $2^{*}$ & S \\
\hline & 78 & IPP, manufacturing & $2015=100$ & CSO - Prices & $2^{*}$ & $S$ \\
\hline & 79 & IPP, electricity, gas, steam and air conditioning supply & $2015=100$ & CSO - Prices & $2^{*}$ & S \\
\hline & 80 & IPP, water supply; sewerage, waste management and remediation & $2015=100$ & CSO - Prices & $2^{*}$ & $\mathrm{~s}$ \\
\hline & 81 & Market services price indices in the business sphere, total & $2015=100$ & CSO - Prices & $2^{*}$ & S \\
\hline & 82 & Inflation expectations of non-financial corporations and companies & $\%$ & CNB, ARAD & 1 & $\mathrm{~F}$ \\
\hline & 83 & Financial market inflation expectations & $\%$ & CNB, ARAD & 1 & $\mathrm{~F}$ \\
\hline & 84 & Repo rate -2 weeks & $\%$ & CNB, ARAD & 1 & $\mathrm{~F}$ \\
\hline & 85 & PRIBOR 3M & $\%$ & CNB, ARAD & 1 & $\mathrm{~F}$ \\
\hline & 86 & PRIBOR 1Y & $\%$ & CNB, ARAD & 1 & $\mathrm{~F}$ \\
\hline & 87 & Government bond yield $2 Y$ & $\%$ & CNB, ARAD & 1 & $\mathrm{~F}$ \\
\hline & 88 & Government bond yield $5 Y$ & $\%$ & CNB, ARAD & 1 & $\mathrm{~F}$ \\
\hline & 89 & Government bond yield $10 \mathrm{Y}$ & $\%$ & CNB, ARAD & 1 & $\mathrm{~F}$ \\
\hline & 90 & Bank interest rates on CZK-denominated loans, households total & $\%$ & CNB, ARAD & 1 & $\mathrm{~F}$ \\
\hline & 91 & Bank interest rates on CZK-denominated loans, households, up to $1 Y$ & $\%$ & CNB, ARAD & 1 & $\mathrm{~F}$ \\
\hline & 92 & Bank interest rates on CZK-denominated loans, households, up to $5 Y$ & $\%$ & CNB, ARAD & 1 & $\mathrm{~F}$ \\
\hline 宸 & 93 & Bank interest rates on CZK-denominated loans, households, over $5 Y$ & $\%$ & CNB, ARAD & 1 & $\mathrm{~F}$ \\
\hline 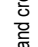 & 94 & $\begin{array}{l}\text { Bank interest rates on CZK-denominated loans, households consumer credit } \\
\text { - total }\end{array}$ & $\%$ & CNB, ARAD & 1 & $\mathrm{~F}$ \\
\hline 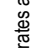 & 95 & $\begin{array}{l}\text { Bank interest rates on CZK-denominated loans, households for house } \\
\text { purchase - total }\end{array}$ & $\%$ & CNB, ARAD & 1 & $\mathrm{~F}$ \\
\hline 岕 & 96 & $\begin{array}{l}\text { Bank interest rates on CZK-denominated loans, households other loans - } \\
\text { total }\end{array}$ & $\%$ & CNB, ARAD & 1 & $\mathrm{~F}$ \\
\hline & 97 & Bank interest rates on CZK-denominated loans, non-financial corporations & $\%$ & CNB, ARAD & 1 & $\mathrm{~F}$ \\
\hline & 98 & $\begin{array}{l}\text { Bank interest rates on CZK-denominated loans, non-financial corporations, } \\
\text { up to } 1 Y\end{array}$ & $\%$ & CNB, ARAD & 1 & $\mathrm{~F}$ \\
\hline & 99 & $\begin{array}{l}\text { Bank interest rates on CZK-denominated loans, non-financial corporations, } \\
\text { up to } 5 Y\end{array}$ & $\%$ & CNB, ARAD & 1 & $\mathrm{~F}$ \\
\hline & 100 & $\begin{array}{l}\text { Bank interest rates on CZK-denominated loans, non-financial corporations, } \\
\text { over } 5 Y\end{array}$ & $\%$ & CNB, ARAD & 1 & $\mathrm{~F}$ \\
\hline & 101 & Monetary base, monthly average & Billions CZK & CNB, ARAD & 2 & $\mathrm{~F}$ \\
\hline & 102 & Monetary aggregate $\mathrm{M} 1$ & Millions CZK & CNB, ARAD & 2 & $\mathrm{~F}$ \\
\hline & 103 & Monetary aggregate M2 & Millions CZK & CNB, ARAD & 2 & $\mathrm{~F}$ \\
\hline & 104 & Loans to residents and non-residents - MFIs & Millions CZK & CNB, ARAD & 2 & $F$ \\
\hline
\end{tabular}




\begin{tabular}{|c|c|c|c|c|c|c|}
\hline & 105 & Loans to non-financial corporations - MFIs & Millions CZK & CNB, ARAD & 2 & $\mathrm{~F}$ \\
\hline & 106 & Loans to financial corporations - MFIs & Millions CZK & CNB, ARAD & 2 & $\mathrm{~F}$ \\
\hline & 107 & Loans to government & Millions CZK & CNB, ARAD & 2 & $\mathrm{~F}$ \\
\hline & 108 & Loans to households & Millions CZK & CNB, ARAD & 2 & $\mathrm{~F}$ \\
\hline & 109 & Loans, short-term (up to $1 Y$ ) & Millions CZK & CNB, ARAD & 2 & $\mathrm{~F}$ \\
\hline & 110 & Loans, medium-term (up to $5 \mathrm{Y}$ ) & Millions CZK & CNB, ARAD & 2 & $\mathrm{~F}$ \\
\hline & 111 & Loans, long-term (over $5 \mathrm{Y}$ ) & Millions CZK & CNB, ARAD & 2 & $\mathrm{~F}$ \\
\hline & 112 & Consumption loans, total & Millions CZK & CNB, ARAD & 2 & $\mathrm{~F}$ \\
\hline & 113 & Mortgages, total & Millions CZK & CNB, ARAD & 2 & $\mathrm{~F}$ \\
\hline & 114 & Other loans, total & Millions CZK & CNB, ARAD & 2 & $\mathrm{~F}$ \\
\hline \multirow{19}{*}{ 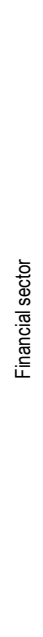 } & 115 & Capital adequacy ratio, total & $\%$ & CNB - non-public data & 1 & $\mathrm{~F}$ \\
\hline & 116 & Leverage ratio, total & $\%$ & CNB - non-public data & 1 & $\mathrm{~F}$ \\
\hline & 117 & Risk-weighted assets to total assets & $\%$ & CNB - non-public data & 1 & $\mathrm{~F}$ \\
\hline & 118 & Non-performing loans to total assets & $\%$ & CNB - non-public data & 1 & $\mathrm{~F}$ \\
\hline & 119 & Loans to total assets (LTA) & $\%$ & CNB - non-public data & 1 & $\mathrm{~F}$ \\
\hline & 120 & Spread (difference between $10 \mathrm{Y}$ gov. bonds yield and PRIBOR 3M) & $\%$ & own calculation & 1 & $\mathrm{~F}$ \\
\hline & 121 & Composite indicator of sovereign stress & $0-1$ interval & ECB & 1 & $\mathrm{~F}$ \\
\hline & 122 & Financial cycle indicator & $0-1$ interval & CNB - non-public data & 1 & $\mathrm{~F}$ \\
\hline & 123 & Index PX & value & PSE & 2 & $\mathrm{~F}$ \\
\hline & 124 & MFI total assets & Millions CZK & CNB - ARAD & 2 & $\mathrm{~F}$ \\
\hline & 125 & House price index & $2010=100$ & CSO - Prices & 2 & $\mathrm{~F}$ \\
\hline & 126 & Banks provisioning & value & CNB - non-public data & 2 & $\mathrm{~F}$ \\
\hline & 127 & House price gap - CNB calculations & value & CNB - non-public data & 1 & $\mathrm{~F}$ \\
\hline & 128 & Overvaluation of commercial property prices - CNB calculations & value & CNB - non-public data & 1 & $\mathrm{~F}$ \\
\hline & 129 & Capital surplus & Millions CZK & CNB - non-public data & 2 & $\mathrm{~F}$ \\
\hline & 130 & Insurance companies and pension funds & Millions CZK & CNB, ARAD & 2 & $\mathrm{~F}$ \\
\hline & 131 & Money market funds & Millions CZK & CNB, ARAD & 2 & $\mathrm{~F}$ \\
\hline & 132 & Investment funds & Millions CZK & CNB, ARAD & 2 & $\mathrm{~F}$ \\
\hline & 133 & Other financial intermediaries (financial vehicle corporations) & Millions CZK & CNB, ARAD & 2 & $\mathrm{~F}$ \\
\hline \multirow{6}{*}{ 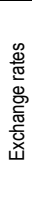 } & 134 & Real effective exchange rate & $2015=100$ & CNB, ARAD & 2 & $\mathrm{~F}$ \\
\hline & 135 & Nominal exchange rate CZK/EUR, monthly average & value & CNB, ARAD & 2 & $\mathrm{~F}$ \\
\hline & 136 & Nominal exchange rate CZK/GBP, monthly average & value & CNB, ARAD & 2 & $\mathrm{~F}$ \\
\hline & 137 & Nominal exchange rate CZK/USD, monthly average & value & CNB, ARAD & 2 & $\mathrm{~F}$ \\
\hline & 138 & Nominal exchange rate CZK/JPY, monthly average & value & CNB, ARAD & 2 & $\mathrm{~F}$ \\
\hline & 139 & Nominal effective exchange rate & $2015=100$ & CNB, ARAD & 2 & $\mathrm{~F}$ \\
\hline \multirow{21}{*}{ 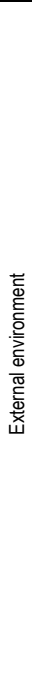 } & 140 & Government bond yield $2 Y$ - eurozone & $\%$ & CNB, ARAD & 1 & $\mathrm{~F}$ \\
\hline & 141 & Government bond yield $5 \mathrm{Y}$ - eurozone & $\%$ & CNB, ARAD & 1 & $\mathrm{~F}$ \\
\hline & 142 & Government bond yield $10 \mathrm{Y}$ - eurozone & $\%$ & CNB, ARAD & 1 & $\mathrm{~F}$ \\
\hline & 143 & Yield spreads on risky private sector bonds & value & CNB - non-public data & 2 & $\mathrm{~F}$ \\
\hline & 144 & Crude oil, Brendt, $\$ / b b l$, current Europe & USD/barrel & EIA & 2 & $\mathrm{~F}$ \\
\hline & 145 & Crude oil, Brendt, \$/bbl, current US & USD/barrel & EIA & 2 & $\mathrm{~F}$ \\
\hline & 146 & Crude Oil Production, US fields & thousand barrels & EIA & 2 & $\mathrm{~F}$ \\
\hline & 147 & Composite indicator of systemic stress, eurozone & index 0-1 & ECB & 1 & $\mathrm{~F}$ \\
\hline & 148 & EURIBOR 3M & $\%$ & ECB & 1 & $\mathrm{~F}$ \\
\hline & 149 & GDP, chain index volumes, Eurozone (changing composition) & $2010=100$ & Eurostat & 2 & $\mathrm{~F}$ \\
\hline & 150 & DAX index & value & Datastream & 2 & $\mathrm{~s}$ \\
\hline & 151 & Industrial production index, total Germany & $2005=100$ & Eurostat, ipp_st_m & 2 & $\mathrm{~S}$ \\
\hline & 152 & Ifo - Business Climate Index, Germany & $2005=100$ & CESifo & 2 & $\mathrm{~S}$ \\
\hline & 153 & All Commodity Price Index & $2005=100$ & IMF & 2 & $\mathrm{~S}$ \\
\hline & 154 & Non-Fuel Price Index & $2005=100$ & IMF & 2 & $\mathrm{~S}$ \\
\hline & 155 & Food and Beverage Price Index & $2005=100$ & IMF & 2 & $\mathrm{~s}$ \\
\hline & 156 & Industrial Inputs Price Index & $2005=100$ & IMF & 2 & S \\
\hline & 157 & Agricultural Raw Materials Index & $2005=100$ & IMF & 2 & S \\
\hline & 158 & Metals Price Index & $2005=100$ & IMF & 2 & S \\
\hline & 159 & Fuel (Energy) Index & $2005=100$ & IMF & 2 & S \\
\hline & 160 & Crude Oil (petroleum), Price index & $2005=100$ & IMF & 2 & $\mathrm{~s}$ \\
\hline
\end{tabular}


The table 1 shows all time-series incorporated in the analysis. Used abbreviations stands for: $\mathrm{CSO}=$ Czech Statistical Office, CNB - Czech National Bank database ARAD, IMF - International Monetary Fund database, ECB - European Central Bank Statistical Data Warehouse. The transformation codes (TC) are: 1 - no transformation; 2 - first difference of logarithm. An asterisk, '*', next to the transformation code number denotes a seasonally adjusted variable using CENSUS X13. S/F ranks variables as slow or fast moving in the estimation.

\section{B. Financial cycle in the Czech Republic}

\section{Figure 1B. Financial cycle and its phases.}

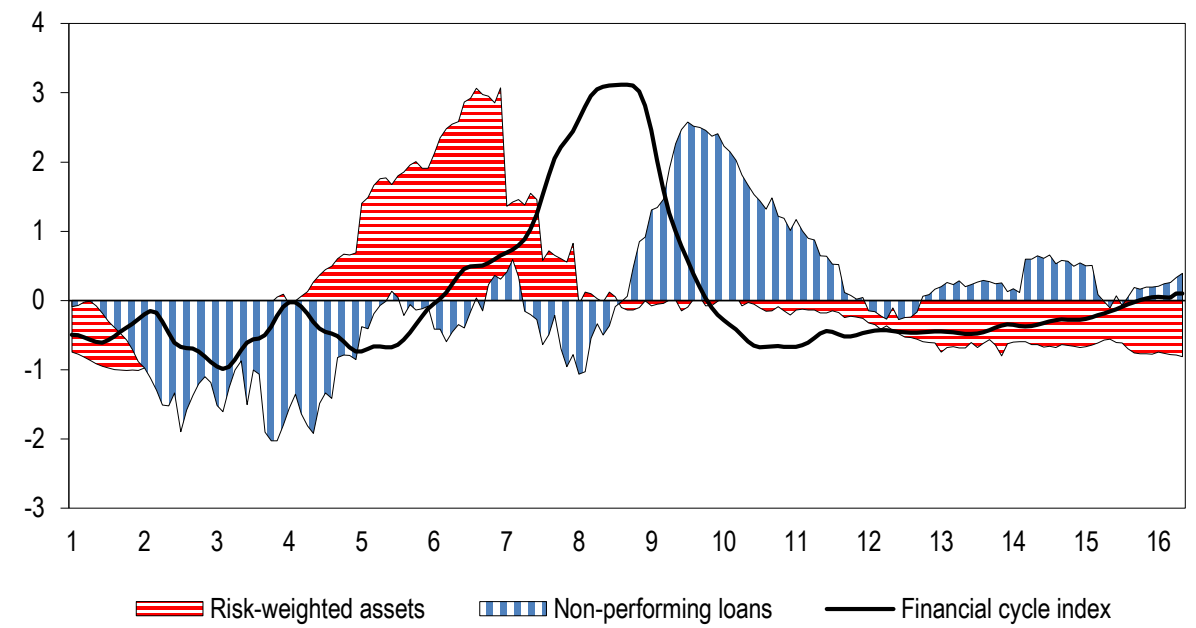

The figure shows the evolution of risk-weighted assets and non-performing loans in the Czech Republic over the time period from 2001 to 2016. The data are compared with the evolution of an official financial cycle index which is described in Plašil et al. (2014). The variables are in percentage change over the previous year. For the sake of clarity, the variables were $\mathrm{z}$-score normalized. It shows that the pre-crisis development can be well associated with the accumulating of risks as evident from the risk-weighted assets build-ups. On the contrary, the post-crisis period is characterized by increasing NPLs, which indicates an increase in the amount of failures and delinquencies in the economy.

\section{Details of the FAVAR Estimation Procedure}

The model is estimated in five steps. First, all factor models require an initial step prior the estimation to determine the optimal number of factors used. One possibility is to use the Bai-Ng information criterion to determine the number of factors present in the macroeconomic data vector $X_{t}$. However, as shown by Tuzcuoglu and Hoke (2016), different time spans might lead to different numbers of factors. Also, the Bai- $\mathrm{Ng}$ criterion does not solve the issue of how many factors we should include in the VAR model itself. We recommend using the following General-to-Specific approach: (i) estimate the mod- 
el with a large number of factors; (ii) check the correlations of every single variable with the estimated factors; (iii) eliminate those factors which do not yield a statistically significant correlation with any group of variables in $X_{t}$; (iv) check that the simplified model remains congruent.

In our application, we have used between 3 and 7 factors; the model with 3 latent factors provides the highest explanatory power and its results are therefore reported in the main text. In Table 1C, we check the correlations of sub-groups of variables with the estimated factors. Visual inspection helps us to determine the actual interpretation of these factors. The first factor loads on real economic variables, coupled with prices. The positive correlations accumulated in second factor correspond at most to credit and financial sector related variables. The third factor explains the external development, which is of great importance to the Czech economy. The remaining fourth and fifth factors are mostly insignificant in terms of correlations, which only justifies estimating the FAVAR model with just three latent factors.

Table 1C: Sub-groups in the Dataset

\begin{tabular}{llll|ll|ll}
\hline \hline Data Sub-groups & F1 & F2 & F3 & F4 & F5 & F6 & F7 \\
\hline Real economy & $\mathbf{0 . 4 6 4}$ & 0.148 & -0.191 & -0.070 & -0.015 & -0.035 & 0.101 \\
Labour market & 0.289 & 0.151 & 0.110 & -0.096 & 0.072 & 0.056 & -0.081 \\
Government & 0.233 & -0.546 & -0.108 & -0.016 & 0.031 & 0.168 & -0.170 \\
Prices & $\mathbf{0 . 4 1 5}$ & -0.102 & 0.087 & 0.083 & 0.199 & 0.068 & 0.011 \\
Interest rates and credits & -0.107 & $\mathbf{0 . 3 1 3}$ & 0.197 & 0.063 & -0.054 & -0.083 & 0.015 \\
Financial sector & 0.006 & $\mathbf{0 . 2 4 0}$ & 0.188 & 0.108 & -0.069 & 0.081 & 0.043 \\
Exchange rates & -0.153 & -0.031 & -0.015 & -0.014 & 0.025 & 0.134 & 0.034 \\
External environment & 0.128 & 0.136 & $\mathbf{0 . 4 1 3}$ & 0.210 & -0.004 & 0.091 & 0.071 \\
\hline Factor 1 & 1 & & & & & & \\
Factor 2 & 0.068 & 1 & & & & & \\
Factor 3 & 0.006 & -0.061 & 1 & & & & \\
Factor 4 & 0.031 & 0.057 & -0.056 & 1 & & & \\
Factor 5 & 0.023 & -0.013 & -0.011 & 0.002 & 1 & & \\
Factor 6 & 0.019 & -0.008 & -0.019 & 0.009 & 0.006 & 1 & \\
Factor 7 & -0.020 & 0.084 & -0.028 & 0.010 & 0.018 & 0.074 & 1 \\
\hline \hline
\end{tabular}

Notes: Table shows average correlations between sub-groups of variables with five estimated factors. Correlations that are significantly different from zero are highlighted in bold. Note that we estimate three independent models using 3, 5 and 7 factors.

Second, we follow Stock and Watson (2002) and divide our panel of variables into two groups: slow- and fast-moving variables. Then, we use a two-step principal components approach, which is a nonparametric way of estimating the space spanned by the common components $C_{t}^{\prime}=\left(F_{t}^{\prime}, Y_{t}^{\prime}\right)$ in (2). The common components $C_{t}$ are estimated using the first $\mathrm{K}+\mathrm{M}$ principal components of $X_{t}$. Note that we impose the factor restriction (as in Bernanke et al., 2005), which identifies the factors against any rotations. $F_{t}{ }^{\prime}$ is obtained as the part of the space covered by $C_{t}{ }^{\prime}$ that is not covered by $Y_{t}$. In our application, we assume that the vector $Y_{t}$ holds only the specified innovations. As such, the $Y_{t}$ may be treated as a separate factor with pervasive effect on the rest of the econ- 
omy $\left(X_{t}\right)$. In other words, for the two-step approach to work, our identification scheme requires first controlling for the part of $C_{t}{ }^{\prime}$ that correspond to the innovation in $Y_{t}$. The following regression is estimated in the process: $C_{t}{ }^{\prime}=b_{F} F_{t}{ }^{\prime S}+b_{Y} Y_{t}+e_{t}$ where $F_{t}{ }^{\prime S}$ are slow-moving factors estimated from the slow-moving variables and $F_{t}^{\prime}=C_{t}^{\prime}-b_{Y}^{\prime} Y_{t}$. Third, the loading matrixes are fitted into a VAR framework, estimated by the standard method, with $F_{t}$ being replaced by $F_{t}{ }^{\prime}$. Fourth, the VAR is estimated and identified recursively using the ordering specified in the main text. Fifth, we construct confidence bands of the impulse response functions using a bootstrap-after-bootstrap technique proposed by Kilian (1998).

\section{Fiscal-monetary policy interactions.}

Figure 1D. Propagation of fiscal and monetary policy shocks and their mutual interaction

Fiscal and monetary policy innovations

Reponses of the main policy variables
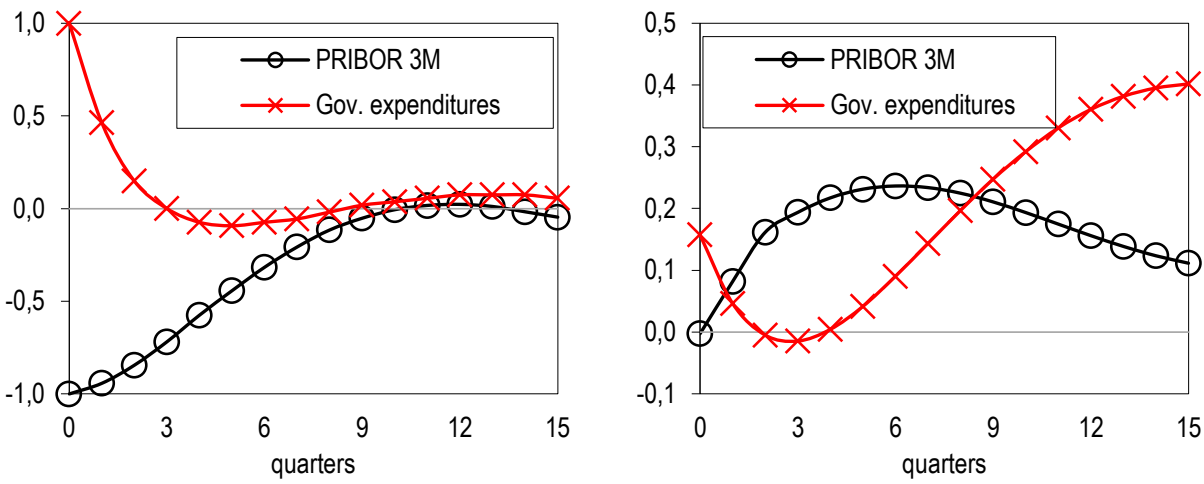

Notes: Median impulse responses are taken from the FAVAR model with 3 factors. The $y$-axis measures the strength of variables response in percentages.

The figure provides only a rudimentary comparison of the identified fiscal and monetary policy innovations and their propagation over a time horizon of four years, as well as a quick look at their mutual interactions. It shows that the fiscal expansion is identified as rather short-lived. The shock lasts four quarters before returning to the long-term equilibrium. On the contrary, the monetary expansion reveals a longer-lasting impact on the studied system. Turning to the mutual fiscal-monetary interactions, the time series evidence suggests that, in short, increasing government expenditures (fiscal expansion) causes monetary policy tightening, while releasing monetary policy allows fiscal policy to expand as well. This is quite logical and expected given both economic policies' primary targets. The Figure also shows that fiscal expansion raises inflation, so any central bank under the inflation-targeting regime is obliged to prevent such inflationary pressures and increase its policy rates in response. On the other hand, monetary expansion decreases the debt service costs of outstanding government debt. Fiscal policy is thus 
free to support the monetary expansion by raising its expenditures. Similar policy behaviour was documented in Mountford and Uhlig (2009) using US data, Haug et al. (2013) for Poland and Dungey and Fry (2009) for New Zealand. 